\title{
A CONTRIBUTION TO THE STUDY OF THE RAINFALL MAP OF SOUTH AFRICA.**
}

\author{
By J. R. Sutton. \\ (With thirteen Maps.) \\ "When the clouds shake their hyssops, and the rain \\ Like holy water falls upon the plain, \\ 'Tis sweet to gaze upon the springing grain \\ And see your harvest born."-Ledwidge.
}

\section{Introduction.}

In the rainfall tables at the end will be found full particulars of the mean monthly and mean annual rainfall for 567 stations in South and East Africa. These have been computed from all the information available in the published reports of the meteorological services of the various States. Occasional items have been extracted from the 'Meteorologische Zeitschrift,' the 'Quarterly Journal of the Royal Meteorological Society,' Symons's 'Meteorological Magazine,' and the Northern News. Besides this the directors of some of the services have kindly furnished special information on request; friends have obtained and forwarded returns from stations in the Bechuanaland Protectorate; and resident magistrates and police officers have helped materially. Consequently it is now possible to give a very much larger and truly representative account of South African rainfall than it was possible to give in a previous discussion. $\dagger$

The tabulated averages now given, dealing with some 8800 years of record altogether, have, with few exceptions, been computed by me alone. The work has been gone over two or three times in order to ensure accuracy, but with such a mass of material it would be a wonder if there were no mistakes at all. Certainly there are not many.

The aim throughout has been to use all existing records running into ten years or more, and in areas where gauges are numerous this rule has been

* The tables and maps here given were prepared five years ago; but, for various reasons, it has not been possible to publish them before.

† J. R. Sutton, "An Introduction to the Study of South African Rainfall," "Trans. Phil. Soc. S. Afr.,' May, 1904. This dealt with 160 stations having records of long periods. 
adhered to. But in areas not well supplied with gauges records of shorter period have had to be admitted, since it has seemed better to get an approximation to the average rainfall at such places than to ignore them altogether. Naturally the means given in the table are not all of the same value; short-period records cannot be expected to give such good mean values as long-period records do, and all observers are not equally faithful.

A common fault in every country is the omission to register small falls of rain, because, forsooth, the observer thinks them too contemptible to bother about. A scrutiny of the returned number of days of rain is sufficient in most cases to reveal this fault; and when there are two or three gauges in one town the record containing the greatest number of rainy days is usually taken as the standard. When there is only one gauge, even when the number of days of rain reported seem to be rather too few, the record of quantity has been used for what it is worth. It is a pity that some observers do not realise that the trouble they take in measuring the heavy falls of rain is largely labour in vain, in a scientific sense, unless they take pains over the smaller falls. Generally speaking the longer records are the most trustworthy, especially when they are the work of one observer. This is because the observer who has enough intelligent energy to go on recording the rainfall year after year does not shirk the measurement of the smaller quantities. Nevertheless there is at least one long-period record in the Cape Province of little scientific value simply because only the heavy falls of rain have been regarded as worth bothering about. It cannot be insisted upon too often that the lighter rains must be as carefully looked after as the heavier ones. For one thing, if there be a secular change of climate anywhere it must proceed very slowly, and the facts can only be discovered by a uniform system of observation which does not neglect small things.

The latitudes, longitudes and altitudes stand, as far as possible, for the latest determinations. In a few cases they have been measured off roughly from maps. The numbers under the heading "years" do not necessarily stand for an unbroken period, although they mostly do. Sometimes they represent two or more periods of observation alternating with longer or shorter intervals during which no records were kept. In such cases the number of years is really the quotient of the number of months divided by twelve. Thus at Lilyfontein (III A, 44) from 1885 to 1908 only ten full years of observation are known; but there were further odds and ends running into fifty-eight months, making 178 months in all, which we call fifteen years.

Occasionally a rain record has been started at one spot, and continued at another not far away. If the aspects and altitudes of the two places are not materially different such a record has been regarded as continuous. For instance a part of the Dumbiedykes rainfall was really observed at Geelbeks Vley a few miles off; and the means for Sea Point have been made 
up from quite a number of separate records from here and there in a small area. One or two combinations of this sort have been done for East African stations, but some amount of caution will be requisite before accepting the results.

In only one instance has any interpolation been attempted, namely, for the Devil's Peak lower gauge, in which an eleven years' record period, 1896 to 1906 , has been proportionally reduced in harmony with the Nursery and Blockhouse gauges to the thirteen years' period 1896 to 1908 .

With some slight modifications, the rainfall areas I to XVII are those used by the late Meteorological Commission of Cape Colony, and established, so to speak, under those numbers by many years of use. Some of these areas are large, and it has been thought best to subdivide them. Thus Section IX has been subdivided into IX A (West) and IX B (East). Sections XVIII to XXX are additional.

The mean monthly falls for each section, or subdivision, have been computed, not necessarily by way of showing the average fall over the area (though it probably does show that with some degree of precision), but rather to trace the tendency of the monthly variations-which is the wet season and which the dry.

\section{Notes on the Rainfall Tables.}

\section{Cape Peninsula.}

This small area, scarcely larger than the smallest English county, has a distribution of rainfall probably more varied than that of any other equal area in all Africa. From its position on the west side of the Continent it stands within a dry region, but the contour of the land alters the conditions, and transforms the dryness into an abundant precipitation over the greater part, which rises like an oasis out of an arid region. The stations in the table showing the least rainfall are Blaauwberg Strand (I, 2) and Cape Point $(\mathrm{I}, 3)$, with annual averages of $13.94 \mathrm{in}$. and $12.70 \mathrm{in}$. respectively, these two stations being some thirty miles apart, one near the extreme north and the other near the extreme south of the peninsula. But according to Sparrman it never rains at all on the flats immediately to the south of Table Mountain*-a remarkable fact if true, seeing that Wynberg (I, 19), on the edge of the flats, has no less than $44 \frac{1}{2}$ in. a year. Along the Atlantic side of the peninsula the rainfall is only moderate, averaging about $20 \mathrm{in}$. a year, Signal Hill (I, 13) with 18.52 in. and Sea Point (I, 12) with 21 in. The east, i.e. the landward side, is, however, wet, ranging between Rondebosch (I, 10) 42.56 in., Platteklip (I, 8) 45.34 in., Bishop's Court $(\mathrm{I}, 1) 57.90$ in. 'The effect of altitude is well shown by the Devil's Peak gauges, the lower gauge (I, 4) at something over $1000 \mathrm{ft} .47 .02 \mathrm{in}$., the

* 'A Voyage to the Cape of Good Hope,' Second Edition, 1786, p. 34. 
Blockhouse, at $1500 \mathrm{ft} ., 58 \cdot 67 \mathrm{in}$. The slopes of Table Mountain show the same tendency, the rainfall at St. Michael's (I, 71) being not far short of 76 in. a year, while Disa Head, a dry station for its altitude, more than $500 \mathrm{ft}$. lower, has only $40 \mathrm{in}$. So far as is known the wettest place in the peninsula is Maclear's Beacon on the top, and near the eastern escarpment of the mountain $(\mathrm{I}, 16 \mathrm{~A})$, with an annual average of $89 \cdot 30 \mathrm{in.}$ *

The annual curve of rainfall is fairly simple, with a maximum in June and a minimum in February. But there is just a tendency towards a small secondary maximum in August, in response to continental conditions.

\section{South-Western Cape Province.}

This area includes the districts of Caledon, Stellenbosch, Paarl, Robertson, Tulbagh, Ceres, and Worcester south of the Hex River. The mean annual rainfall varies from 11.43 in. at Worcester (II, 38) to 40.89 in. at Ceres (II, 21), only twenty miles away. The majority of the stations have upwards of 20 in. a year. Probably one of the wettest stations in South Africa is situated in this area, i.e. at Berg River Hoek, No. 9 Gauge, on the western slope of the Hottentot's Holland Mountains, in lat. $33^{\circ} 55^{\prime}$, long. $19^{\circ} 4^{\prime}$. The altitude is not given. Two years of observation at this spot gave a mean rainfall of no less than $115 \mathrm{in}$. a year.

The annual curve of rainfall resembles that of $I$, but the August maximum is more strongly marked.

\section{Western Cape Province.}

Comprises the whole western side of Cape Colony from Bok Point to the Orange River. It has been subdivided here into III A (Namaqualand), and III B (the districts of Van Rhyns Dorp, Clanwilliam, Piquetberg, and Malmesbury). The rainfall decreases rapidly as we go north, ranging all the way from $24 \cdot 21$ in. at Saron (III B, 57) to 2.28 in. at Port Nolloth (III A, 47). For Namaqualand, Lilyfontein has quite an exceptional rainfall.

The August maximum, though quite obvious, is somewhat more uncertain than it is in II. Also as we go north we find a retrogression of the first maximum into May, and a corresponding retreat of the minimum into January; inland, at Pella (III A, 46), the maxima one in March and October, the minima in July and November.

\section{Southern Cape Province.}

Comprises the whole of the south coast districts of Cape Colony from Cape Agulhas to Algoa Bay. The rainfall increases gradually on the whole

* See T. Stewart, “The Rainfall of Table Mountain,” “Trans. R. Soc. S. Afr.,' iii, 1913. The averages for the "Additional Stations" are taken from this paper. As much as 36.58 in. in one month (August, 1899) has been recorded at Maclear's Beacon. 
from west to east, and from the coast inland to the outer slopes of the Langebergen and Outniquas Mountains. On the other side of the coast ranges, whose spurs, jutting south-east, form the heads of Cape St. Francis and Cape Recife, the fall is again less, as Uitenhage (IV B, 80), 17.09 in., and Dunbrody (IV B, 73), 15.58 in.

In the western half of this area there is a long-drawn-out maximum of precipitation from February to May, and a shorter one in October. In the eastern half there are maxima from March to May and in SeptemberOctober. In both halves the minima are in January and July.

\section{Southern Karroo.}

The Western lialf, called the Little Karroo on some maps, of this area is the terrace which lies between the Langebergen and Groote Zwartebergen, forming as it were the first step up from the coast plains. The rainfall is poor, the rain-bearing clouds having deposited much of their excess of moisture on the southern slopes of the first range of mountains inland. There are two maxima in the year, roughly in March and October, but varying in epoch from one station to another. The summer minimum is also of somewhat uncertain epoch, but the winter minimum is fairly sure in July.

The eastern half stretches across the spurs, which strike seawards to the north of Cape St. Francis. If there were any truth in the popular idea of "south-east rain-bearing winds" this area would have a copious rainfall instead of less than Uitenhage and Dunbrody. There are maxima near the times of the equinoxes, minima about the middle and end of the year.

\section{West Central Karroo.}

The Great Karroo of the maps. It is bounded on the north by the Nieuwveld Range, on the south by the Groote Zwartebergen, and on the west by the Bontebergen, its eastern boundaries being ill-defined along the middle reaches of the Groote River.

The western half, i.e.VI A, may be regarded as the second step up from the coast belt to the table-land, and shows the effect of a still further depletion of the clouds in the second range of mountains inland. Only one station in this area has a good rainfall, namely Zwartberg Pass (VI A, 101), in the mountains, with $27 \cdot 41$ in. There are two annual maxima, about the time of the equinoxes, with minima in July and November.

The eastern half, VI B, stretching from the Nieuwveld Range to the Baviaans River, differs from the western half not only in its greater rainfall, but more particularly that it has only one maximum and minimum of precipitation in the year, the former being in March and the latter in July. On this account Beaufort. West would perhaps have been more at home in VI B. Nelspoort (VI B, 104) and Lówer Nelspoort (VI B, 105) are similarly 
situated and only some four or five miles apart, and hence each gives practically the same information.

\section{East Central Karroo.}

Comprises the districts of Graaff Reinet, Somerset East, Jansenville, and a portion of Aberdeen. The rainfall is of a similar character to that of VI B. Somerset East (VII, 122) is, properly speaking, a sort of salient from $\mathrm{X}$, but the region north, south and west of Somerset East is typical Karroo.

\section{Northern Karroo.}

Extending from Namaqualand on the west to the Great and Little Winterberg on the east; is actually the southern portion of the table-land. The western half, VIII A, of this has generally a single maximum and minimum of rainfall in the year, i.e. in March and August. Some of the stations on the lower slopes to the west-south-west still show, however, the double maximum and minimum of VI A. In the direction of Namaqualand the country is very sparsely inhabited, and only one record of rainfall, namely that of Brandvlei (VIII A, 129), has so far been discovered in it, and that for only five years. The Gannapan (VIII A, 133) numbers are almost certainly too low. The eastern half, VIII B, has the March maximum, but the minimum is nearly a month early, falling in July.

\section{Northern Cape Province.}

This area is bounded by Namaqualand on the west to the Orange River Colony on the east, and includes all the northern provinces of Cape Colony. Upington is on the north bank of the Orange River, The Halt is some distance to the north of the river on the border of Great Namaqualand, both these stations being really in Gordonia. Van Wyks Vlei would perhaps be better included in VIII A, excepting that the Karreebergen to the south cut it off from that area. The annual curve of rainfall is of the simple type, with one maximum in March and one minimum in August. The rainfall at Groet Boetsap is exceptionally great considering its position. The Kimberley rainfall includes Kenilworth, and goes back to 1874 .

\section{South-Eastern Cape Province.}

This region of abundant mean rainfall, watered by the Buffalo, Keiskama, Kei, Kunap, Great Fish, Kowie and Bushman Rivers is better represented by rain-gauges than any other excepting the Cape Peninsula. And it has been possible to select no less than twenty-eight stations, each having a record extending over more than twenty years of, generally speaking, good observing.

The southern slope of the Amatola Mountains in this area is the wettest 
known spot in Cape Colony outside Table Mountain and the Hottentot's Holland, and includes Evelyn Valley (X 190) with $65 \cdot 17$ in. a year, and the Hogsback with 43 in. With the exception of Alicedale (X, 182) and Daggaboer $(\mathrm{X}, 187)$ no station in this area has a smaller mean annual rainfall than 20 in.; but these two stations, which are on the extreme west of $\mathrm{X}$, might very well have been included in VII.

On the whole there is a single maximum and minimum in the year, namely, about February or March and July respectively. But several stations, particularly those not far from the coast, show a second maximum in October-November, e.g. East London, Port Alfred, and Alexandria (X, 189, 203 and $180 \mathrm{~A}$ ).

Though well watered on the whole this area is subject to droughts lasting for some weeks. At Alexandria there has been one November with 11 in., and the next November not half an inch. It appears that occasionally the Karroo conditions of VII push right down to the coast.

\section{North-Eastern Cape Province.}

Includes the high country lying between the Orange Free State and $\mathrm{X}$. It is now fairly well supplied with gauges and good observers, and sixteen have records of over twenty years' duration. It has a pretty good rainfall of the simple type, with its maximum in February and its minimum in July. The rapid increase of quantity from November to December is noteworthy. The area is crossed by the watershed of the Stormbergen, but this range has no such effect upon the rainfall as the ranges further west, the stations to the north of it having at least as good a fall as those to the south.

\section{Kaffraria.}

The eastern portion of Cape Colony lying between Natal and the Great Kei River. It is separated from Basutoland on the north-west by the Drakensbergen. The rainfall is abundant everywhere, and excepting near the coast has one maximum and minimum in the year, at about midsummer and midwinter. Going inland up the slopes of the river valleys the mean annual rainfall first diminishes and then increases-again, a circumstance which to some extent reverses the effect due to altitude (see under XV and $\mathrm{XVI}$ ).

\section{Basutoland.}

Rainfall stations only exist in this area along the settled valley of the Caledon River. Nothing is known of the rainfall of the highlands lying between the Maluti and Quathlamba Mountains, which form fully threequarters of the country; but that the fall is considerable is proved by the numerous streams which form the headwaters of the Orange River. We should conclude from the volume and number of these streams that, if anything, considerably more rain falls upon the western slopes of the mountains of Basutoland than upon the eastern slopes facing the sea. And 
this conclusion is confirmed by the testimony of the rain-gauges, so far as they go, Mount Fletcher (XII, 237) and Matatiele (XII, 236) having each a less precipitation than Mozeni (XIII, 253) and Qachas Nek (XIII, 254) across the mountains. Every station in Basutoland has a rainfall of at least 30 in., whereas in Kaffraria only six stations, including St. John's, exceed that round value.

Here, again, the rainfall is of the simple type with a January maximum and July minimum.

\section{Orange Free State.}

All Basutoland lying between the western slopes of the Maluti Mountains and the Caledon River belongs to the same geophysical area as the Orange Free State, and stations like Wepener (XIV, 272) and Ladybrand (XIV, 267 ), near the right bank of the river, have rainfalls similar to those of the left bank in XIII. Going towards the west, however, the conditions become more and more arid, Jacobsdal (XIV, 264) and Philippolis (XIV, 269) having mean annual falls not much greater than that of Kimberley.

Mr. F. S. Lynch, the General Manager of the Kimberley Waterworks Company, has kindly given me the following additional information. His letter is dated October 19, 1915.

Vrede: Average rainfall during the past ten years $26 \cdot 6$ in.

Parys : Average rainfall 21·16 in.

Reitz: Average rainfall approximately $30 \mathrm{in.}$

Senekal: Average rainfall, 1905 to $1913,26 \cdot 68 \mathrm{in}$.

Bethlehem: Average rainfall during the last ten years 28.824 in.

Heilbron: Average rainfall for past five years $25 \cdot 45 \mathrm{in}$.

In each case the information was supplied by the postmaster of the town mentioned.

\section{XV and XVI. Natal and Zululand.}

Saving the Cape Peninsula this is one of the most interesting rainfall areas in South Africa. It may be divided roughly (and the same division applies also to Kaffraria) into three zones. (1) A zone of heavy precipitation, 40 in. a year and more, along the coast belt; $(2)$ decreasing gradually to a moderate rainfall, 25-30 in., down the centre of the country; and (3) increasing again gradually to upwards of $30 \mathrm{in}$. under the shadow of the Drakensbergen. Inland there is one maximum near midsummer, and one minimum near midwinter. On the coast there are two maxima, in March and October-November, and two minima, about January and July. According to Mann the rainfall of Natal is caused by two essentially distinct influences: first, by the development in summer of storms more or less of the character of thunderstorms, which most powerfully affect the inland districts and the uplands; and secondly, by the occurrence of sea gales, which fall with most violence upon the coast and the lands in the 
close neighbourhood of the sea,* and which come at any season, though perhaps the most pronounced of them have been in the winter. The sea-gale rainfalls are almost invariably associated with a high barometer, while the thunderstorms are as characteristically low-barometer phenomena. Since the winds of Maritzburg, where Mann's observations were taken, are chiefly east to south-east, this observer concluded that Natal must be within the zone of the south-east trade winds, and get its rain from them. Further up the coast, however, in the district of Lourenço Marques, the rainfall becomes less-a fact which does not support Mann's idea. Moreover the same easterly and south-easterly winds blow also in the winter when the interior of Natal is dry.

A typical instance of heavy winter rain occurred on the Natal coast May 31-June 1, 1905, when the following rainfalls were registered in 24 hours-

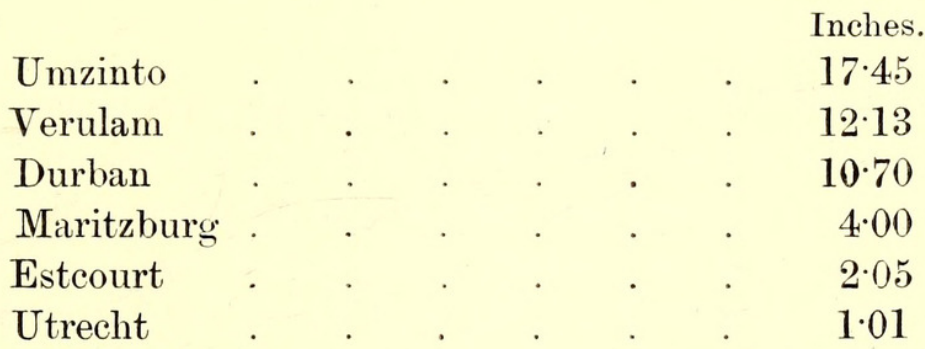

showing a progressive decline of intensity as the storm worked inland. It is indeed these sea rains which make up the high mean winter rainfall of the whole eastern coast belt, saving that of Lourenço Marques, from Port Alfred to the tropics.

The following list shows how the annual rainfall varies going from west to east across the Continent, between latitudes $29^{\circ}$ and $30^{\circ} \mathrm{S}$. :

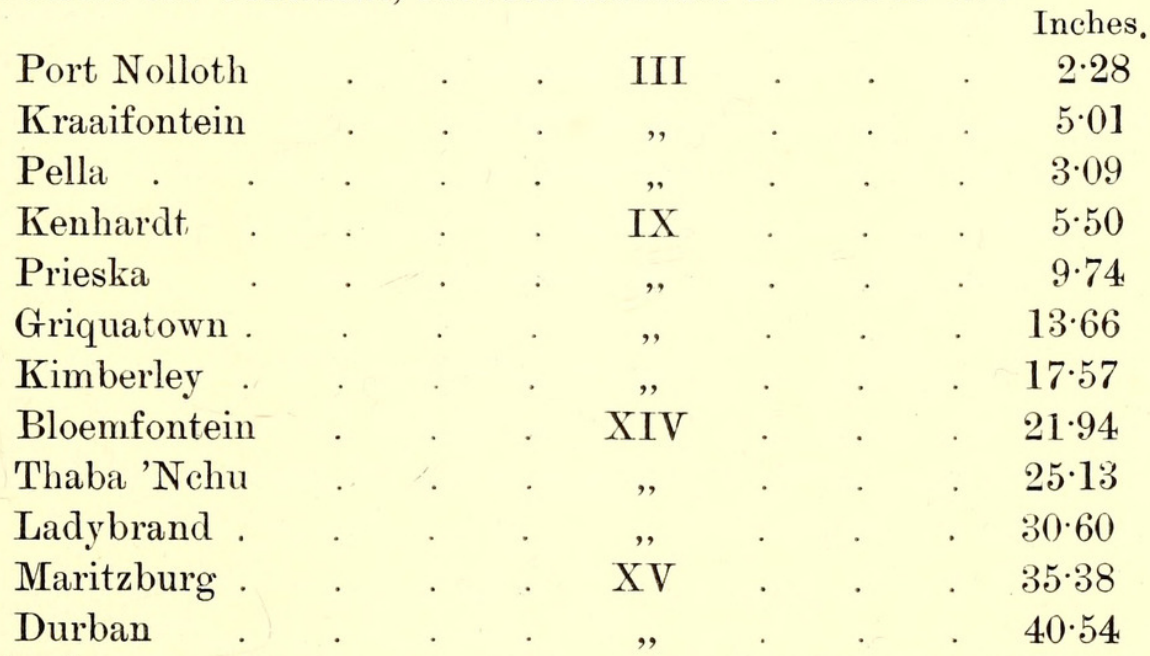

This gives an annual average increase of rainfall of about one inch for each 22 miles further east. Between Port Nolloth and Kimberley there is

* R. J. Mann, "Contributions to the Meteorology of Natal," 'Quart. Journ, Met. Soc.,' October, 1878. 
an extra inch for each 30 miles; between Kimberley and Durban the increase is $1 \mathrm{in}$. for each 17 miles.

\section{Bechuanaland.}

A remarkable feature here is the exceptionally high rainfall of Mafeking. No very obvious explanation of this circumstance is forthcoming; but the rainfall over the greater part of this area is very variable from year to year, floods alternating with long droughts, and Mafeking may have got more than its share of the former. The run of the averages for Palapye Road and Serowe (XVII, 318, 319) is interesting, and not the less so because no particulars of the rainfall of Chief Khama's headquarters have hitherto been published. Another interesting and new station is Tsau, on the northern border of Lake Ngami. Though the record here summarised is a short one, it suggests that some previous assumptions regarding the rainfall round about the Lake were quite wrong.

\section{Damaraland and Great Namaqualand.}

In this interesting region we have desert conditions on the coast belt, with a gradual improvement from west to east and from south to north. To the north-east the general rain conditions are at least as good as those of Griqualand West (compare XVIII and III with IX). A remarkable feature is the rapidity with which the type changes from a winter to a summer rainfall in the vicinity of the Orange River.

\section{XIX-XXIII. Transvaal.}

This area is not strictly comparable with the others. The mean January, February and March rainfalls for nearly all the stations are artificial, January counting from 1-30, March from 2-31, and February from January 31 to March 1. Few of the stations have much of a record, the exceptions being the mining areas. The fall increases from west to east on the whole. It is high in the north-east highlands, but falls off over the lower levels adjacent to the Portuguese border and Rhodesia. It is mostly thunderstorm rain, with a summer maximum and minimum.

\section{XXIV and XXV. Southern Rhodesia.}

This area also shows the increase of rain from west to east. It shows also on the whole a heavier summer and a lighter winter rainfall than the Transvaal and Bechuanaland do.

\section{Portuguese East Africa.}

Most of these stations are on the coast. 'The rainfall varies very much from one year to another, so that the shor:t records cannot possibly give very good averages. Thus while five years of published observations at Beira gave a mean annual rainfall of nearly $51 \mathrm{in}$., the inclusion of a further 
seven years' record, hitherto unpublished, lowered the mean to less than 45 in. Places near latitude $24^{\circ}$ S., especially when they project beyond $35^{\circ}$ E., have a large winter fall made up apparently of storms similar to those which assail Natal.

\section{British Central Africa.}

A region of abundant mean summer rainfall. Though entirely within the tropics it shows no definite indication of a double annual period. The maximum of intensity, however, appears to come progressively later as we go north, shifting from January to March in eight or nine degrees of latitude. The Nyassa Highlands are the only places where any rain to speak of falls between May and October. Lauderdale (XXVII, 500) appears to be almost the only station in South Africa which lives up to the traveller's wonders of rainfall described in pen and pencil books.

Nearly all the material in XXVII is now published for the first time.

\section{East Africa.}

The general tendency is to maxima in April, July and November. Inland the July maximum disappears, and the November maximum comes later. The scheme of distribution of the rain over all this area is evidently most complicated, and requires more gauges to the square mile for its elucidation than any other area south of the equator. Aspect nearly everywhere is of more importance than elevation, some of the loftiest stations being among the driest. Compare, e g., Amani with Kwai (XXVIII, 508, 519), Ruteganio (XXVIII, 531) with Fife (XXVII, 495).

\section{British East Africa.}

These particulars have been transcribed from one of the Government reports, and include only recent observations. There appears to be a dry area protruding inland from near the equator and dividing the wet coast from the wet lakes. Thus we have Mombasa (XXIX, 548) with an annual fall of 55.68 in. and Port Florence (XXIX, 555) with 46.60 in.; whereas Kismayu (XXIX, 539) has but 17.08 in., Athi River (XXIX, 536) 25.08 in., and Nakuru (XXIX, 554) 33.24 in.

Various annual mean falls for longer periods than seven years are:

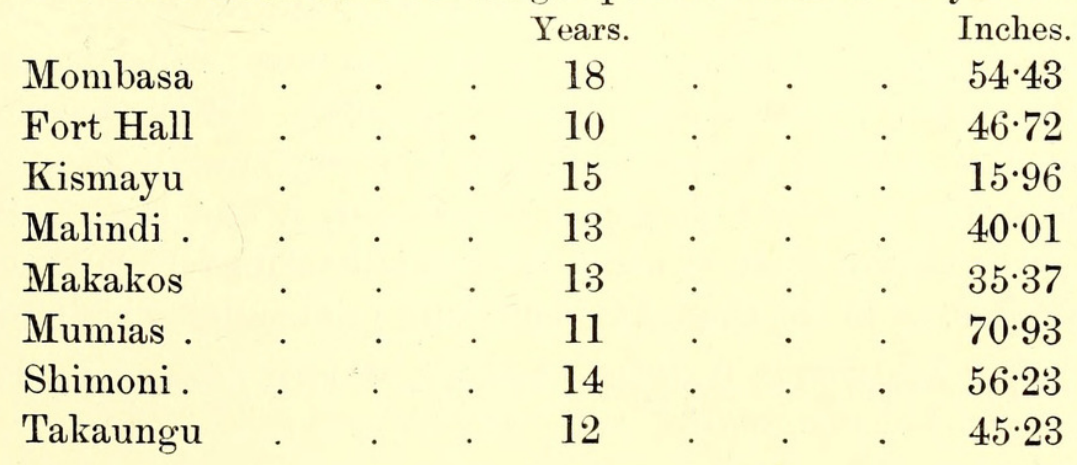




\section{Notes on the Rainfall Maps.}

Some preliminary monthly maps of the rainfall of Cape Colony and the Orange Free State were drawn by Gamble and published in the Report of the Meteorological Commission for 1886. As the observing stations were few in those days, and the records of no great length, there was necessarily a good deal of imagination in the maps, and they only show in a rough way which places are wet and which dry on the whole in given months. Buchan constructed some monthly maps of the rainfall of Cape Colony, the Orange Free State, and parts of Natal and the Transvaal, based upon his discussion of the rainfall of the ten years 1885-94. These were published by the Meteorological Commission in 1897 and were a marked improvement upon Gamble's. They have been reproduced in Bartholomew's 'Physical Atlas,' 1899, and in various other publications. Of the 278 stations for which Buchan had the records, however, only about a half extended to the full ten years, the rest running to anything from three years to nine. Knox, in 1911, published a series of elegant monthly maps of the rainfall of Africa in his 'Climate of the Continent of Africa.' These were based upon odds and ends of scrapbook information culled from all sorts of responsible and irresponsible sources; and consequently the beauty of the maps is no guarantee of their accuracy. Fraumberger and Herbertson have dealt with African rainfall at large. Father Goetz published a detailed map of the annual rainfall of Southern Rhodesia in the Meteorological Report of that Colony for 1908.* C. Stewart prepared a very fine map of the average annual rainfall of the Union of South Africa, and another showing the seasonal distribution of rainfall, for the use of the Select Committee of the Senate on Droughts, Rainfall and Soil Erosion.

The rainfall maps now given are intended to represent graphically the broad features of all the results shown by the rainfall tables. In principle the construction of such maps is easy enough. All we had to do is to draw a series of lines, called "isohyets," each one of which shall pass through all stations having a given rainfall. Thus the isoyhet of $1 \mathrm{in}$. (equal to about $25 \mathrm{~mm}$.) will join up in a continuous curve all stations in some particular area whose mean annual (or monthly) rainfall is $1 \mathrm{in.}$ In actual practice it is not so easy to draw these lines as it is to state the way to do it. 'To begin with, very few stations out of the whole number can be found whose annual (or monthly) rainfall is some given quantity. It becomes a question not so much of joining up places having a given rainfall as of drawing an isohyet so that greater falls are on one side of it and lesser falls on the other. Next we have areas in which the rainfall varies very much over very small distances, as in the Cape Peninsula and in mountainous districts here

* See also E. Goetz, "The Rainfall of Rhodesia," 'Proc. Rhodesia Sc. Assoc.,' vol. viii, 1909. 
and there; and it is not always easy to determine whether an isohyet should pass round such a place to the right or to the left. Moreover, in areas where there are few gauges the isohyets are usually drawn too simply straight. So that there is always room for bias, and for criticism, upon the details of any rainfall map, whether those before us or any other.

Looking at the annual map, we see that south of latitude $25^{\circ} \mathrm{S}$. the isohyets trend mainly north and south, while north of latitude $20^{\circ}$ the tendency of the trend is north-west to south-east. A remarkable feature is the dry belt near the tropic of Capricorn, stretching nearly all across the continent, and only broken by the wet oasis of the mountains in the Eastern Transvaal. The course of the isohyets inland from that part of the east coast lying between the parallels of $24^{\circ}$ and $27^{\circ}$ is to some extent tentative. When more rainfall records are available from the gauges Lieutenant Teixeira is establishing in Portuguese East Africa, it will probably be found that the isohyets meander more than they have been drawn to show.

At first sight it might appear that the small closed isohyet of $60 \mathrm{in}$. on the tropic, and that of 50 in. near latitude $27^{\circ}$, ought to be in more intimate communication with one another, and one feels tempted at first to run the isohyet of $30 \mathrm{in}$. inland from about the place where the parallel of $27^{\circ}$ meets the coast, and below the 50 -in. isohyet rather than above it. The intrusion of the isohyet of $20 \mathrm{in}$. from the west, nevertheless, in the immediate neighbourhood, as well as the dry belt pushing westwards from Lourenço Marques, support the map.

It is curious how relatively few conspicuous instances there are in which the mountain ranges show a pronounced influence upon the rainfall. It is evident that the distribution of South African rainfall is of general significance, and that local conditions are quite a secondary matter. Local influence can be traced along the terraces facing the Atlantic, along the Langebergen and Outniquas, in the Amatolas, in the northern end of the Drakensbergen, and, perhaps most strikingly of all, in the Zoutpansbergen, which, as we have seen, is the one obstacle to the uninterrupted course of the tropical dry belt across the continent. Lake Nyassa is an oddity : the Shire Highlands manage to catch the rain; but if the map is to be trusted, the western side of the lake is much wetter than the eastern side in spite of the Livingstone Range.

The most likely explanation of the lack of concordance between the distribution of rainfall and the physical features of the land is that most South African rain falls in thunderstorms, whose origins and tracks are largely independent of the geographical contours, and whose clouds are higher than most of the mountains. Now it is the almost universal custom to fill up by inference the gaps in our actual knowledge of the rainfall, and this usually resolves itself into an effort to make the isohyets and the land contours coincide. Thus if we have a semicircular range of hills with only 
two rain-gauges, one at each extremity, and the mean rainfall at the two gauges is about the same, say $20 \mathrm{in}$., then in nine cases out of ten such the isohyet of $20 \mathrm{in}$. would be drawn with a semicircular sweep to follow the course of the hills, and in eight cases of the nine the isohyet might prove to be nearly correct. Such a plan has been followed to some extent here; but the facts as we find them show that in the lump inference is a poor substitute for knowledge, and that no such success in guessing can be expected in South Africa as is attained in countries where thunderstorms are fewer. Indeed, even in England, where the mean isohyets are almost entirely of geographical inception, Mill has discovered that heavy rain, whether it fall in thunderstorms or during cyclonic disturbances, falls impartially on high or on low ground without any regard to the configuration of the country. "It seems," says Mill, "that the causes determining the fall of rain on these occasions are to be sought in the air alone, and that at a level so far above the surface that inequalities of ground, even amounting to several thousand feet, are without direct influence upon them." * We may understand from this the great want of concordance between the isohyets and the contour of South Africa. If we would discover the reason why our isohyets bend this way or that, we must first discover the reason why thunderstorms form and travel as they do.

The same sort of considerations apply to the monthly maps. If we study them carefully, in order, month by month, we begin to see that the monthly mean rainfall over any area taken at random is not dependent so much upon the impinging of moisture-laden winds from the ocean upon lofty slopes, as upon the more general progressive movements of a rainfall belt to and from the equator.

Consider, e.g., the isohyet of 8 in. In January this bends inland near latitude $17^{\circ}$, follows the course of the Zambesi to near longitude $25^{\circ}$, turns northwards to latitude $10^{\circ}$, crosses and recrosses this parallel, and finally runs down the meridian of $40^{\circ}$ to the sea. Over all the land within this line the mean January rainfall exceeds 8 in. In February we find the area enclosed by the same isohyet somewhat further south, its southern boundary crossing the Zambesi and reaching the coast below Beira. In March it has retreated northwards again, its northern boundary being near latitude $8^{\circ}$, its southern boundary about $14^{\circ}$. In April it has nearly disappeared from the map and does not reappear until December.

In January the 4-in. isohyet meanders from west to east between the 7 th and 30 th meridians above and below the parallel of $21^{\circ}$; it then turns towards the south-west as far as latitude $27^{\circ}$, from whence it wanders south-east to the sea. To the left of this line the rainfall is greater than $4 \mathrm{in}$; t to the right it is less, and it gradually tails off to nearly nothing 1908.

\footnotetext{
* H. R. Mill, “Map-studies of Rainfall,” 'Quarterly Journ. R. Met. Soc.,'April,
} 
along the lower half of the west coast. In February the same isohyet has shifted a little south ; in March it has edged off to the north-east, while in April it is shown running nearly due west to east along the parallel of $11^{\circ}$. It is not drawn on the December map, but its course can be mentally followed between the isohyets of 3 and 5 in., and from these we see that it is pretty much the same as it is in March.

In January the 1-in. isohyet runs south from near the top left-hand corner of the map to latitude $25^{\circ}$, where it curves more to the east. In February it is rather nearer the Atlantic, and in March still nearer-albeit the 2-in. isohyet in this month has pushed out a long tongue eastwards. In April it has moved considerably northwards, and embraces the whole of the interior. In May it has retreated to the equator. In October it begins to show again north of the 15th parallel; and can be followed in November and December closing down upon its first position near the west coast.

Of the other isohyets much the same may be said. In fact they form together one system which moves north and south as the sun moves, but with a lag of a month or more. That is, in September, when the sun is on the equator, going south, the zone of heaviest rainfall is in the northern hemisphere, and it does not reach the equator for upwards of a month; in March, when the sun is again on the equator, going north, the zone of heaviest rainfall extends along the parallel of about $10^{\circ} \mathrm{S}$. This is not to say that the rainfall system retains a uniform aspect as it swings north and south. At one time the isohyets may be closing up together; at another they may be opening out. The isohyets of 1 and 2 in., e.g., are further apart in November than they are in January.

The zero isohyet is interesting. In June it occupies a considerable belt of the country lying between latitudes $5^{\circ}$ and $18^{\circ}$. In July it circuits a much larger area, having extended outwards north and south; but its southward progress has evidently received a check in the high land near the tropic, facing the Atlantic-an indication that occasional though trivial rain falls at this place in July. And, curiously enough, as the area within the zero isohyet comes still further south we see that these reluctant rains invade it for a considerable distance from the south, reducing the area of no rain, in August, by many thousand square miles, and nearly obliterating it altogether in September.

Corresponding to the general movements of the main isohyetal system are the movements of the subsidiary systems found on the coast-the winter rains of the south-west, for example, which advance as the summer rains retreat, and vice versî, and the rains of the south and south-east coastal belt. The winter rains of the south-west do, indeed, now and then, and the southern coastal belt rains not infrequently, push their way inland as far as Kimberley and Bloemfontein. 


\section{Some Details of Rainfall.}

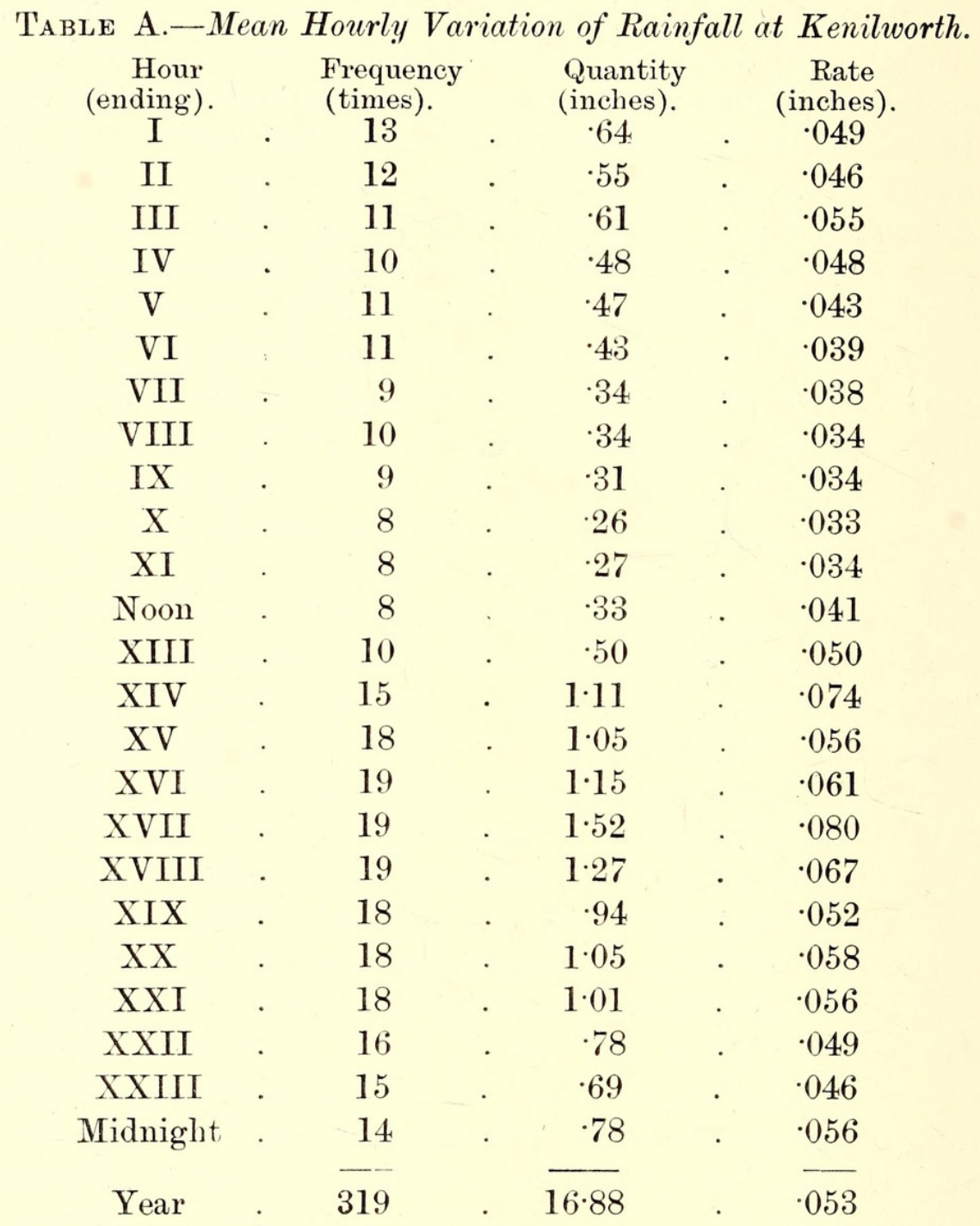

Table A shows how the rate of rainfall varies from hour to hour at Kenilworth (Kimberley). It is deduced from observations made during the 17 years 1897 to 1913 - a period in which the annual average fall was an inch or so less than the normal mean used in IX, 178 of the rainfall table

The numbers under the heading "Frequency" tell how many times on an average it was raining during each given hour throughout the year. Thus for the hour ending 1 a.m. there was, on an average, rain on 13 days of the year; for the hour ending 4 p.m. there was rain on 19 days; and so on. Upon the whole there were 319 hours per annum during which rain was recorded, i.e. less than one hour a day. Since the average number of rainy days at Kenilworth is about 70 , it follows that an average wet day would run to about $4 \frac{1}{2}$ hours of rainfall. 
TaвLe B.-Miscellaneous Details of Rainfall.

\begin{tabular}{|c|c|c|c|}
\hline Section. & $\begin{array}{l}\text { Average number } \\
\text { of rainy days } \\
\text { per annum. }\end{array}$ & $\begin{array}{l}\text { Greatest } \\
\text { rainfall in } \\
\text { one year. } \\
\text { (inches). }\end{array}$ & Heavy rainfall in 24 hours. \\
\hline$I$ & 152 & $126 \cdot 18$ & $\quad 6.00$ at Newlands. \\
\hline II & 110 & $115 \cdot 47$ & . $\quad 5.93$, , Berg River. \\
\hline III & 75 & $34 \cdot 60$ & $3 \cdot 14$, , Dassen Island. \\
\hline IV & 138 & $69 \cdot 27$ & 16.50 , Swellendam. \\
\hline $\mathrm{V}$ & 59 & $28 \cdot 12$ & $4 \cdot 63$,, Kleinpoort. \\
\hline VI & 51 & $47 \cdot 26$ & $5 \cdot 00$ „, Zwartberg Pass. \\
\hline VII & 92 & $44 \cdot 17$ & 4.60 , Somerset East. \\
\hline VIII & 70 & $34 \cdot 81$ & 430 „, Petrusville. \\
\hline IX & 70 & $38 \cdot 47$ & $4 \cdot 60$,, Campbell. \\
\hline $\mathrm{X}$ & 152 & $103 \cdot 11$ & $11 \cdot 33$, Evelyn Valley. \\
\hline $\mathrm{XI}$ & 101 & 56.53 & 5.94 ,, Ellesmere. \\
\hline XII & 130 & $68 \cdot 54$ & $9 \cdot 29$, Flagstaff. \\
\hline XIII & 96 & $49 \cdot 19$ & $4 \cdot 25$, Mafeteng. \\
\hline $\mathrm{XIV}$ & - & $43 \cdot 29$ & - \\
\hline $\mathrm{XV}$ & 162 & $73 \cdot 00$ & $17 \cdot 45$, , Umzinto. \\
\hline XVII & 60 & $28 \cdot 44$ & $5 \cdot 20$,, Vryburg. \\
\hline XIX to XXIII & 86 & - & 4.09 , Pretoria. \\
\hline XXIV & 77 & $45 \cdot 30$ & $5 \cdot 45$, , Gwels. \\
\hline $\mathrm{XXV}$ & 100 & $72 \cdot 15$ & - \\
\hline XXVII & 123 & - & - \\
\hline
\end{tabular}

The average precipitation for each hour is given under the heading "Quantity." The driest hour of the day is 9 to 10 a.m. with scarcely more than a quarter of an inch a year; the wettest hour is 4 to 5 p.m. with six times as much. The hourly quantities are somewhat irregular, probably because 17 years is too short a period to produce a smooth curve.

The numbers under the heading "Rate" specify the average hourly intensity of rainfall. It is deduced by dividing the whole fall per hour per annum by the number of hours it took to fall in, or-

Quantity / frequency $=$ rate.

We see that the hourly average rate of rainfall in wet weather rises and falls as the hourly average frequency increases and diminishes-that is to say, the hour which carries the greatest chance of rain carries the heavier fall when it comes. The lightest rain comes between 7 and 11 a.m., the heaviest in the afternoon.

In Table B some miscellaneous details of rainfall are given, taken mainly from the records of the twelve years 1897 to 1908. The "Average number of rainy days" does not, excepting in a few instances, apply to any one station in a particular section, but is really the average of the greatest 33 
number of rainy days reported, from whatever station in the section, each year. For Section IX the number of rainy days at Kenilworth is used; for XV those of Durban; XIX to XXIII takes Pretoria and Johannesburg; XXIV is for Bulawayo; XXV is for Melsetter; and XXVII is for Zomba. Altogether the section with the greater rainfall has the greater number of rainy days.

A "rainy day" is a day upon which the precipitation is at least $\cdot 01$ in.

The hour at which the rainy day is supposed to end has a curious influence on the number of rainy days in a year. Thus at Kenilworth it makes all the difference whether the day is reckoned from 8 a.m. to 8 a.m., or from 8 p.m. to 8 p.m. In the former case the average number of rainy days for the 14 years 1901 to 1914 is 70 , whereas in the latter case the average number is 75. The reason for the difference is that it rains more often (see Table A) at 8 p.m. than it does at 8 a.m. Suppose it to be raining from 7 to 9 p.m. on June 10, and the hourly fall to be

$$
\begin{array}{lll}
7-8 \text { p.m. } & \cdot & 15 \mathrm{in} . \\
8-9 & \text { p.m. } & \cdot \\
& 12 \mathrm{in} .
\end{array}
$$

This would give us one day's rain of 27 in. for the 24 hours ending 8 a.m. June 11, but one day's rain of $15 \mathrm{in}$. for the 24 hours ending 8 p.m. June 10 , and another of $12 \mathrm{in}$. for the following 24 hours.

In addition to 75 days ( 8 p.m. to 8 p.m.) of rainfall in measurable quantities at Kenilworth in a year, there are 25 more days upon each of which only a few drops are noted.

The "Greatest rainfall in one year" (Table B) applies to any station in a given section. Mostly the wettest years occur at places where the mean rainfall is the greatest.

The last column of Table B gives some typical heavy rainfalls in 24 hours. The quantity shown for Section IV is remarkable. Previous to 1906 the average rainfall for December at Swellendam was $2 \cdot 36$, derived from 25 years of observation. In December, 1906, there were torrents of rain ("cloudbursts" in the vernacular) experienced over nearly the whole of Section IV, and probably the most intense ever known there. In that month 26.72 in. fell at Swellendam and 16.32 in. at Heidelberg, of which 65.01 in. fell in one day at the former place and $11.37 \mathrm{in}$. at the latter.

\section{A Note on South African Hailstorms.}

A good deal of the South African rainfall occurs in hailstorms.

Lenard has found that raindrops exceeding $0 \cdot 1$ in. radius cannot last, but break up into smaller fragments in a very few seconds, while tiny drops can hold themselves intact in strong tumultuous gusts of wind. Hailstones, however, can go on growing even to the size of cricket balls. Some of the 
stones which fell at Maritzburg in April, 1874, were too big to go into a breakfast cup, measured $4 \frac{1}{2} \mathrm{in}$. in one diameter and $3 \frac{1}{2} \mathrm{in}$. in the other and weighed up to $1 \frac{1}{2} \mathrm{lb}$. avoirdupois.* These stones, therefore, were a matter of 65,000 times as large as the largest possible raindrop; their terminal velocity must have been very much greater than that of any raindrop, so that it is no wonder that they crashed through corrugated iron roofs as they would through paper.

Two newspaper accounts of heavy South African hailstorms are given below :

(1) From the Diamond Fields Advertiser of December 12, 1915 :

"Weather Extraordinary: Remarkable Wind and Hail.-The Mafeking Mail on Monday had a report of an extraordinary storm stated to have occurred in the vicinity of Hildavale a few days previously. The full fury of the storm, it was stated, was felt on the farm Raailies Park, while other farms in the neighbourhood to suffer included those of Messrs. Odendaal Van Wijk (De Rust), Adams (Thorn Park), and Greenberg (Crowsley Park). Mr. Durand was reported as having stated that the storm pursued a narrow path about 350 yards wide, and for a distance of a mile every tree and shrub in its course was destroyed. Of the trees many were twisted off at the trunk but the majority were torn out of the ground. Examination of this devastated belt afterwards showed that many of the larger trees were carried away for some 20 yards with their trunks trailing on the ground, and were then lifted clear of the ground and deposited many yards distant. A further and perhaps more telling illustration of the fury of the tornado may be found in the fact that 350 yards of fencing in its path was wholly destroyed-not only were the iron standards twisted in corkscrew fashion and bent, but the strands of wire were broken in many places, doubtless due to the uprooted trees being hurled against them.

"There followed a hailstorm of exceptional violence. Says the paper named: "For nearly five minutes great isolated chunks of ice fell. We have the authority of $\mathrm{Mr}$. Durand for stating that four of these chunks, weighed collectively, turned the scale at $4 \mathrm{lb}$., and the measurements of one were: width 4 in., depth 4 in., and length $4 \frac{1}{2}$ in. Numerous hail-stones weighing over $\frac{3}{4} \mathrm{lb}$. also fell. Into ploughed land the bigger stones penetrated to a depth of from 2 to $3 \mathrm{in}$. and it would be better to imagine than experience a bombardment with such missiles had such been accompanied by a heavy wind.

“ 'As it was, Mr. Durand's losses in livestock were considerable. Of one flock of sheep 14 were killed outright and 16 died later, while 30 or 40 , though very badly bruised and bleeding, are recovering. An ox had its eye

* Natal. 'Commission appointed to Enquire and Report upon the Extent and Condition of Forest Lands in the Colony,' 1880. Also, Rev. J. D. la 'Touche in 'Quart. Journ., R. Met. Soc.', October, 1874. 
destroyed, while a two-year-old heifer belonging to Mr. Du Plessis was killed.

“" Packing cases outside Mr. Durand's homestead were smashed to matchwood. The thatch on two rooms adjoining the homestead was completely demolished, a circumstance which rendered the rooms altogether untenable, while at Mr. Odendaal's homestead one hailstone crashed clean through the verandah roof-of corrugated iron-leaving a hole of about 3 in. in diameter. At the end of five minutes smaller hailstones fell, and continued for some ten minutes. No great quantity of rain fell-in fact just before the water began to " run " on the veldt the storm ceased.'

"Apparently the foregoing details were received with incredulity by the readers of the paper, which on the following day printed a comfirmatory letter from the owner of Thorn Park-Mr. A. E. Adams, who wrote:

“ "On Wednesday we experienced a terrible hailstorm, the like of which I had never before seen. I have often heard of hailstones the size of turkeyeggs, but have not seen them, but some of those that fell on Wednesday afternoon were larger than goose-eggs. The majority were the size of tennis balls. The circumference of one I measured was $13 \frac{3}{4}$ in. one way and $9 \frac{3}{4}$ in. the other, and many weighed just over a pound. Luckily no wind accompanied the hail. I had three sheep killed, while a number had one or more legs broken and their eyes knocked out. Mr. Durand lost 30 sheep, and Mr. Du Plessis a cow.

" My garden was knocked to atoms; scarcely anything is left. Galvanised iron was dented all over, and a few holes were knocked in the iron. Any number of springbok and stembok were killed over on the flats.' "'

(2) From the same paper of January 3, 1916:

“Mr. J. Allen, of Kildavale, Rhodesia, writes to the Bedford paper as follows: On December 15 we had an exceptionally heavy hailstorm here, in which the hailstones were the largest ever seen by inhabitants of this part of the country. On this farm they were as large as tennis balls. We measured four of them, the largest being $13 \frac{1}{2} \mathrm{in}$. in circumference, and weighing little over half a pound, and the remaining three measuring between 10 and 12 in. A neighbour, however, seems to have beaten this, one measuring $18 \mathrm{in.}$ in circumference and weighing a pound. The storm lasted about ten minutes, the hail being small at first, and increasing in size. Luckily the storm was not accompanied by wind, otherwise the losses would have been much greater. As it is, one farmer lost 28 sheep killed, and many with legs broken and minus eyes. The cattle had large lumps on their bodies, some also losing eyes. Many holes in the ground caused by the stones were from 1 to $2 \mathrm{in}$. deep. Old natives born here say they have not seen hailstones as large as these." 
6. Bibliography of Special Studies of South African Rainfall not REFERRED TO ABOVE.

Claxton, T. F._- Note on the Connection between the Rainfall of Durban and Mauritius,”' 'Trans. S.A. Phil. Soc.,' 1907.

Cox, G. W._-"The Intensity of Rainfall in the Transvaal," 'S.A. Journ. of Science,' 1916.

Gamble, J. G._-"Rainfall of South Africa," 'Trans. S.A. Phil. Soc.,' 1879. “ Rainfall in South Africa," 'Quart. Journ. R. Met. Soc.,' 1881. "Rainfall on and around Table Mountain," ibid., 1888.

Howard, A. G.- "The Rainfall of South Africa: The Possibility of Prediction over the South West," ‘Trans. Roy. Soc. S. Afr.,' 1910.

Huтchins, D. C._-“ Rainfall of South Africa,” 'Agricultural Journal,' 1897.

Innes, R. T. A.- “'Climate and Rainfall of South Africa," 'Quart. Journ. R. Met. Soc.,' 1911.

ManN, R. J. --“ On the Rainfall of Natal,” ' Quart. Journ. Met. Soc.,' 1868, 1870.

- "On an Exceptionally Heavy Rainfall and a Destructive Flood in the Colony of Natal, etc.," ibid., 1868.

Rendell, R. F._-“Rainfall of Durban, Natal,” 'Quart. Journ. R. Met. Soc.,' 1906.

Statham, F. R.-Mr. Magnus. This novel contains a good description of a hailstorm at Camberton (=Kimberley), 1896.

Sutton, J. R._-“The Working Value of Rainfall,” 'Agricultural Journal,' October, 1912.

TRIPP, W. B.-“ Rainfall of South Africa,” 'Quart. Journ. R. Met. Soc., 1888.

Wood, H. E.- "Snowstorms in the Transvaal," 'S.A. Journ. of Science,' 1910. "The Intensity Distribution of Rainfall over the Witwatersrand," 'Journ. Scot. Met. Soc.,' 1909. 


\begin{tabular}{|c|c|c|c|}
\hline$\ddot{\Xi}$ & 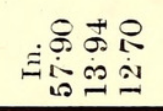 & 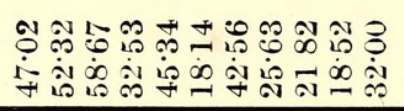 & 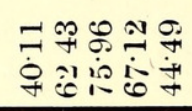 \\
\hline$\stackrel{\check{\Xi}}{\check{\Xi}}$ & 萧合 & 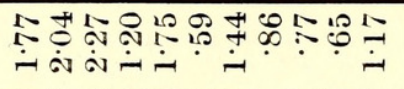 & 要 \\
\hline 㻤 & $9 \stackrel{10}{7}$ & 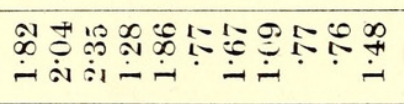 & 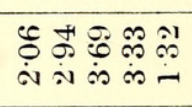 \\
\hline$\dot{0}$ & $\stackrel{10}{10}$ & 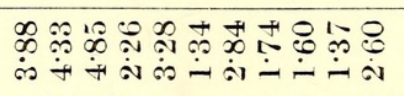 & 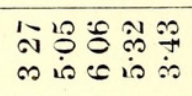 \\
\hline 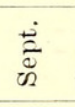 & 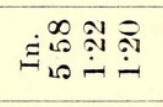 & 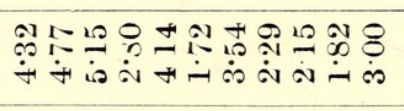 & 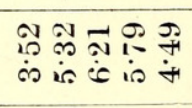 \\
\hline$\dot{80}$ & 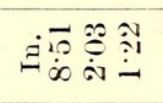 & 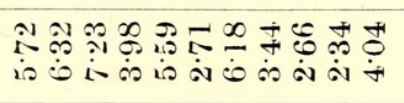 & 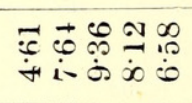 \\
\hline$\dot{\check{g}}$ & & 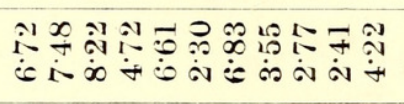 & 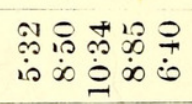 \\
\hline$\stackrel{\dot{\Phi}}{\Xi}$ & 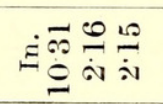 & 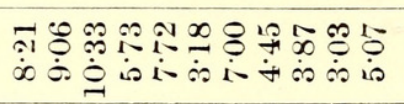 & 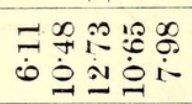 \\
\hline 远 & 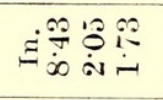 & 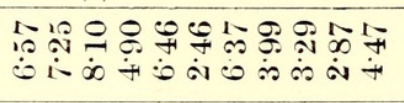 & 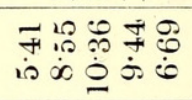 \\
\hline$\dot{\bar{\tau}}$ & & 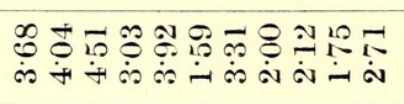 & 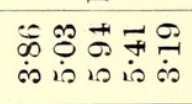 \\
\hline$\dot{\bar{z}}$ & & 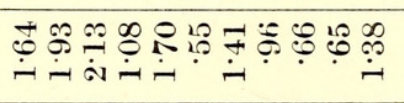 & 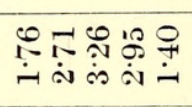 \\
\hline$\dot{\overline{0}}$ & مَّ & 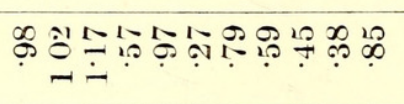 & 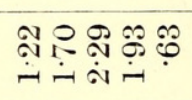 \\
\hline 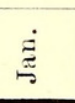 & & 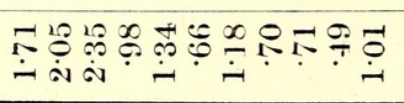 & 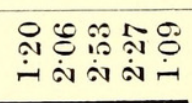 \\
\hline 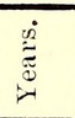 & i $\pm \infty$ & 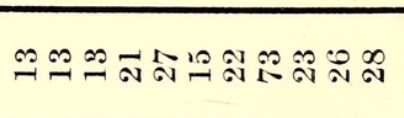 & ลัล゙ニ゙ล̊ \\
\hline$\dot{\sharp}$ & 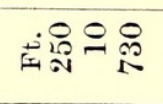 & 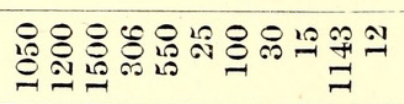 & e. \\
\hline $\begin{array}{l}\dot{\dot{0}} \\
\stackrel{\dot{\sigma}}{\dot{g}}\end{array}$ & $\begin{array}{l}i \rightarrow \infty \\
\stackrel{N}{N} \stackrel{\circ}{\circ} \\
\infty \\
\infty\end{array}$ & 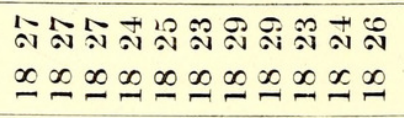 & 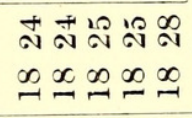 \\
\hline$\stackrel{\dot{I}}{\vec{*}}$ & 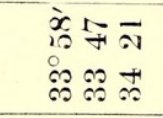 & 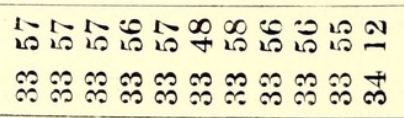 & 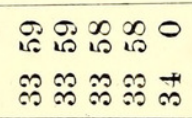 \\
\hline & $\operatorname{ran} 0$ & $+1000 m 00-10 m+$ & \\
\hline
\end{tabular}

的距 सेंक्ष

mon

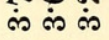

จำ

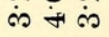

色苍 i $\mathrm{i}$ i

$\infty$ 合里 is $\infty \dot{0}$

into $\dot{\alpha} \stackrel{\sim}{\dot{\Xi}}$

至卡

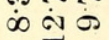

कृष

宅立

요유 i- 0

की $\dot{\gamma} \mathrm{i}$ is

격요 $\dot{\gamma} \boldsymbol{\circ} \dot{0}$

我 200

$\dot{-} \dot{-}$

우우

जे के

$\infty 0 \Omega$

@心

$1+1$

1

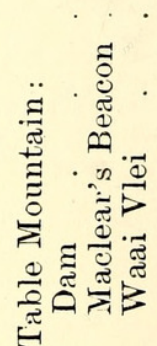

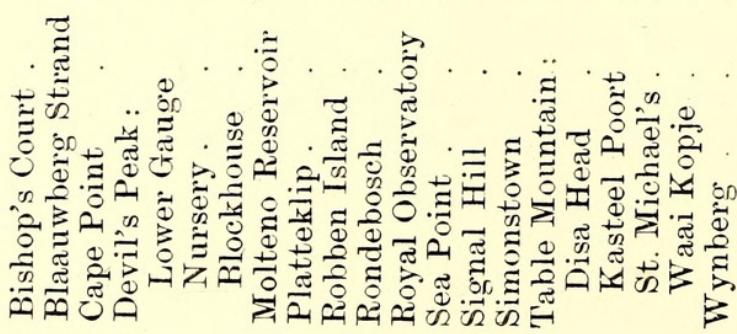


A Contribution to the Study of the Rainfall Map of South Africa. 389

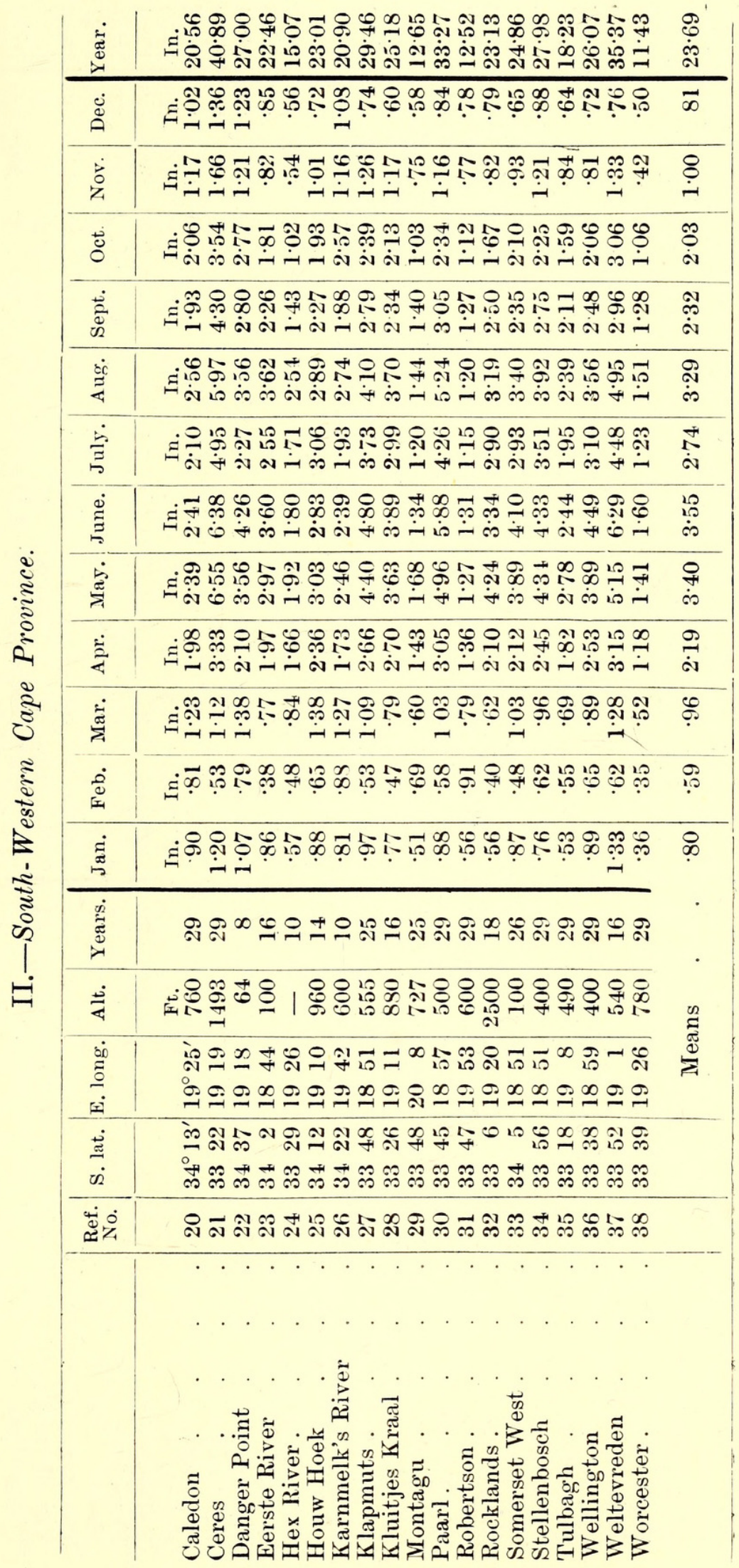




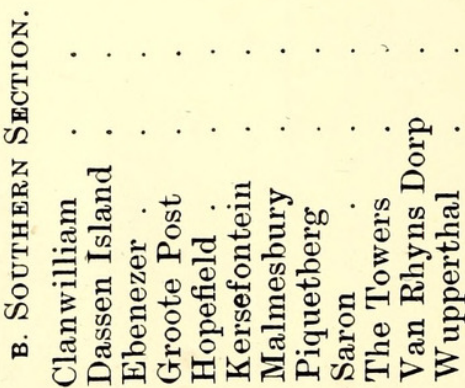




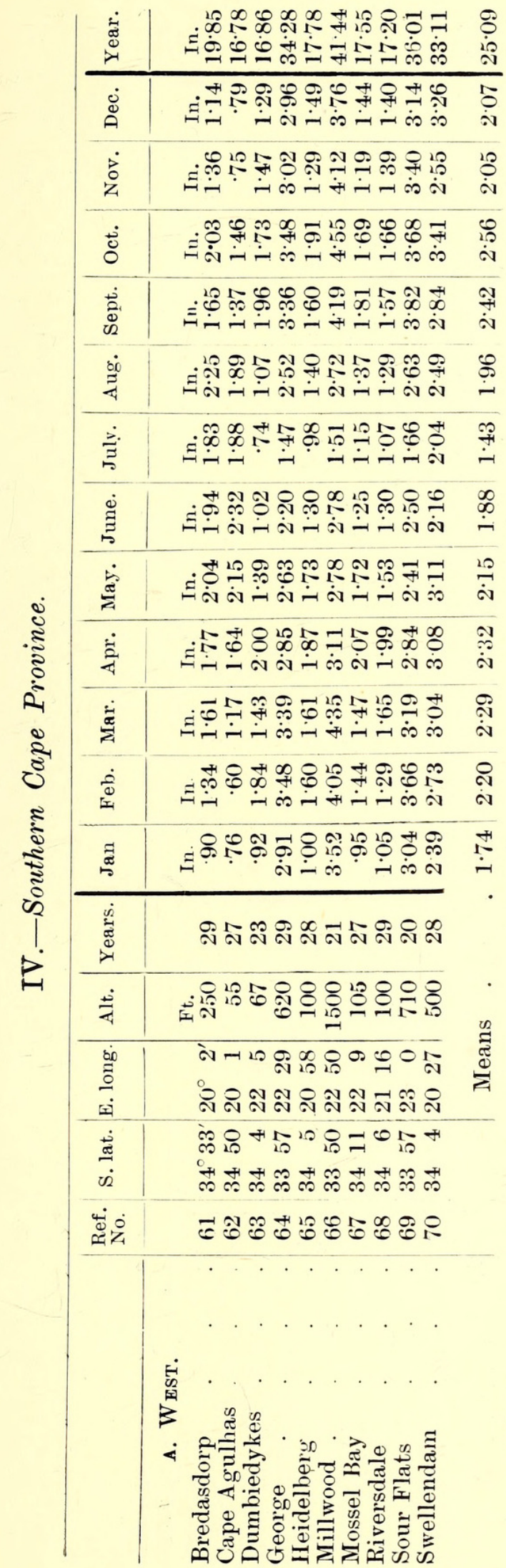

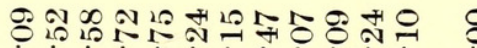

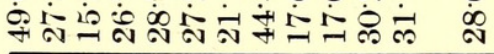

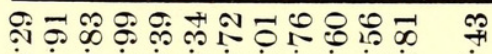

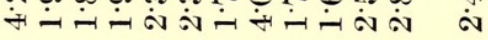

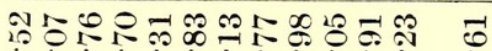
में

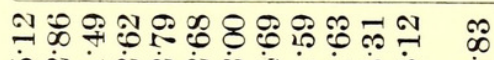

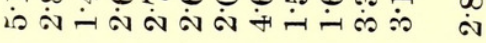

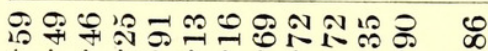
यิ่

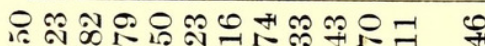

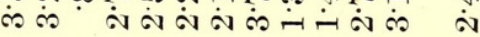

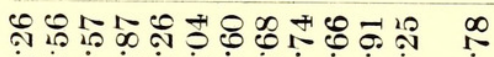

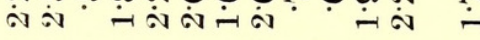

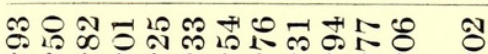

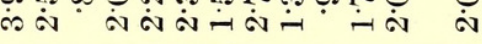

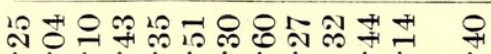

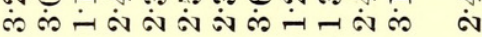

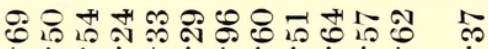
๓

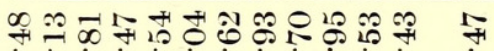
+ 아

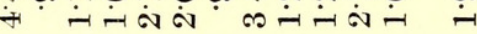

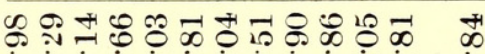

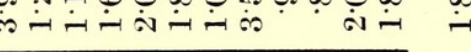

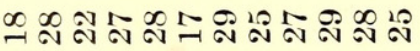

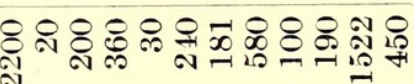
은

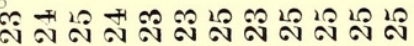

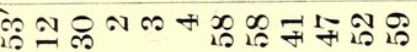

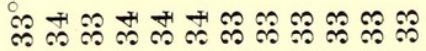

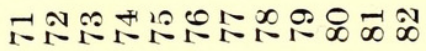

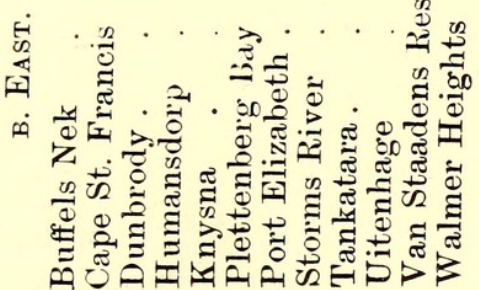




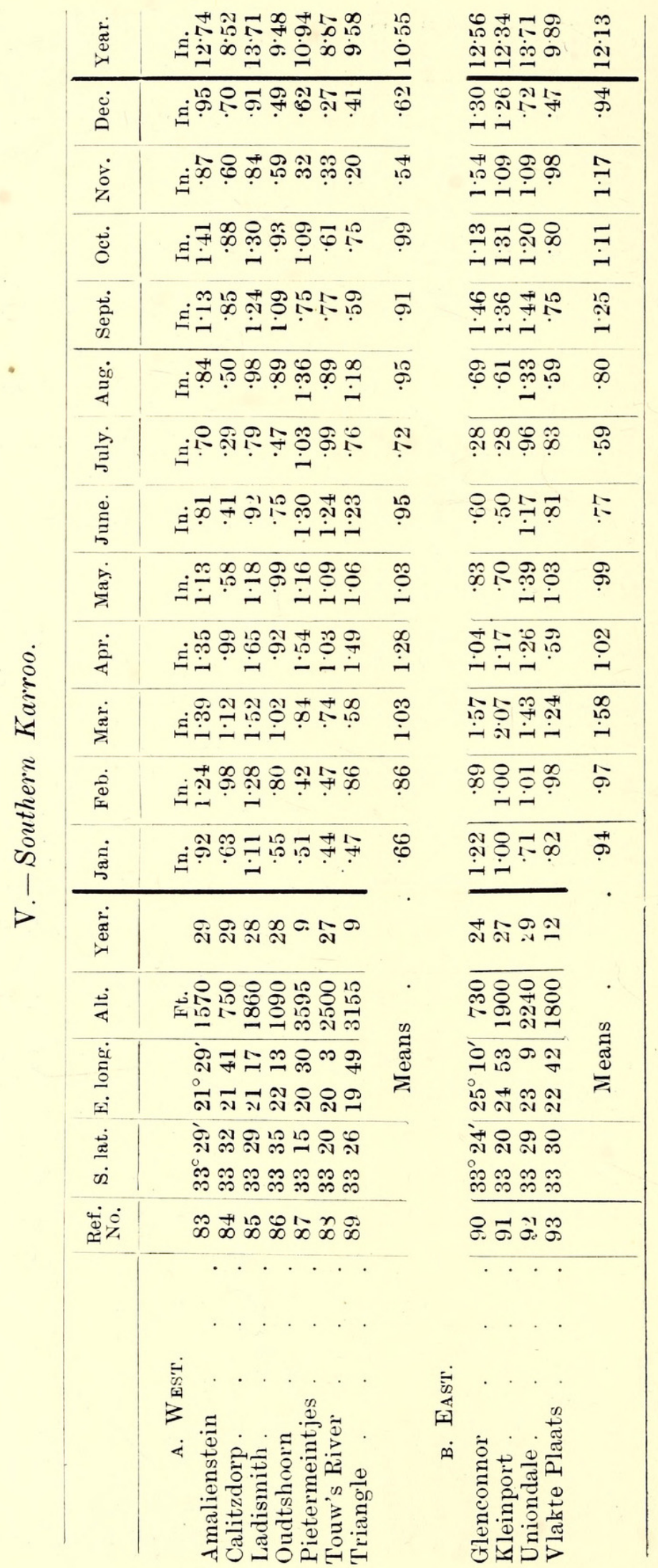


A Contribution to the Study of the Rainfall Map of South Africa. 393

\begin{tabular}{|c|c|c|c|c|}
\hline$\dot{\Xi}$ & 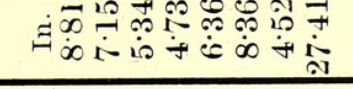 & $\begin{array}{l}\infty \\
\dot{\sigma} \\
\dot{\sigma}\end{array}$ & 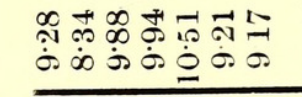 & $\stackrel{\infty}{\dot{\sigma}}$ \\
\hline Ф் & 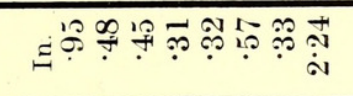 & $F$ & 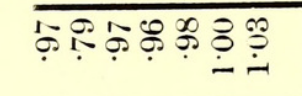 & 8 \\
\hline 高 & 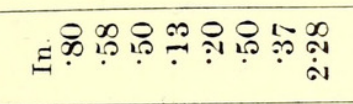 & بَ & 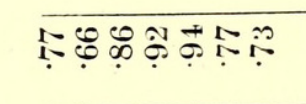 & $\vec{\infty}$ \\
\hline 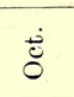 & 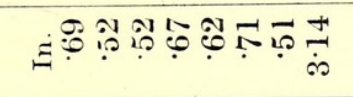 & مे & 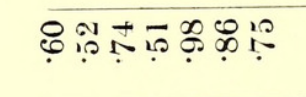 & 눈 \\
\hline $\begin{array}{l}\stackrel{\vec{\Xi}}{0} \\
\text { Uू }\end{array}$ & 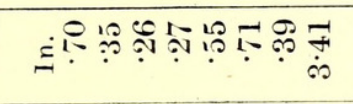 & $\dddot{\wp}$ & 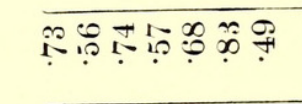 & $\dddot{8}$ \\
\hline$\frac{\dot{\infty} 0}{\bar{\psi}}$ & 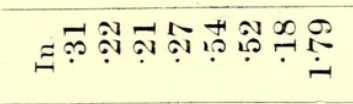 & $\stackrel{8}{?}$ & 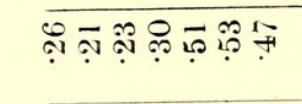 & 6 \\
\hline$\stackrel{\leftrightarrow}{\leftrightarrows}$ & 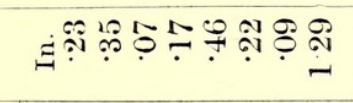 & $\stackrel{\varphi}{\varphi}$ & 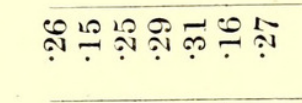 & $\stackrel{+}{a}$ \\
\hline$\stackrel{\dot{g}}{\Xi}$ & 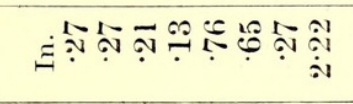 & $\stackrel{8}{0}$ & 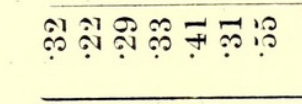 & 80 \\
\hline 远 & 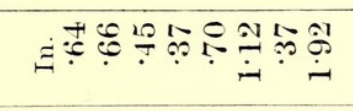 & $\stackrel{\infty}{\mathscr{c}}$ & 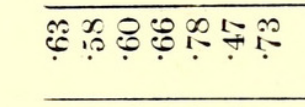 & फ़ं \\
\hline$\dot{\vec{\zeta}}$ & 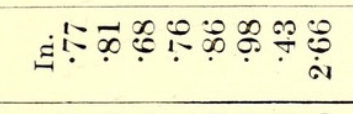 & $\stackrel{9}{\circ}$ & فำ & $\mathscr{\infty}$ \\
\hline$\dot{\Xi}$ & 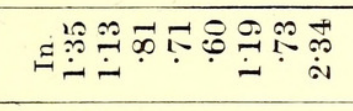 & $\overrightarrow{-}$ & 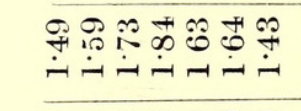 & $\stackrel{\oplus}{\varphi}$ \\
\hline$\stackrel{\overline{0}}{i}$ & 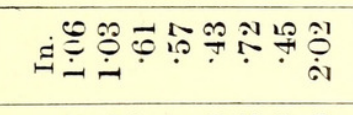 & $\ddot{\infty}$ & 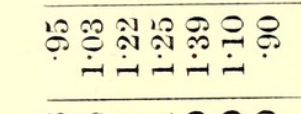 & $\stackrel{\sim}{\ddot{1}}$ \\
\hline 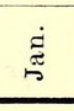 & 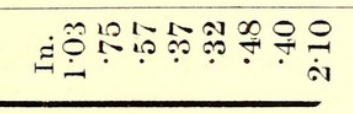 & 10 & 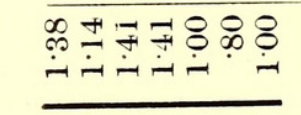 & $\stackrel{0}{\dot{\prime}}$ \\
\hline 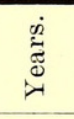 & ㅇำ & · & 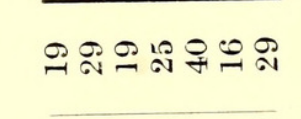 & . \\
\hline$\stackrel{+5}{4}$ & 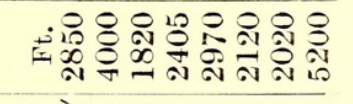 & 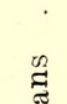 & 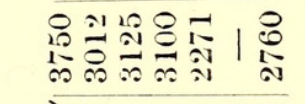 & ¿ี \\
\hline $\begin{array}{l}\dot{0} \\
\dot{0} \\
\stackrel{0}{9}\end{array}$ & 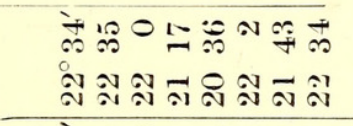 & $\stackrel{\square}{=}$ & 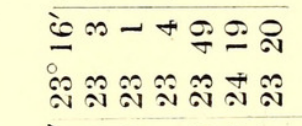 & $\stackrel{\widetilde{d}}{\frac{\pi}{2}}$ \\
\hline$\frac{\vec{a}}{\dot{a}}$ & 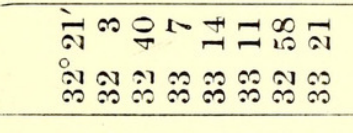 & & 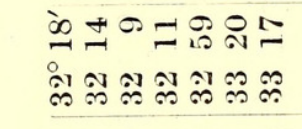 & \\
\hline 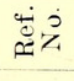 & 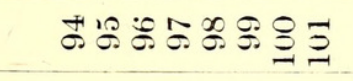 & & ᄋิ & \\
\hline & 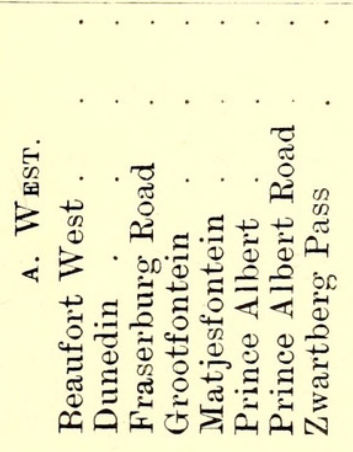 & & 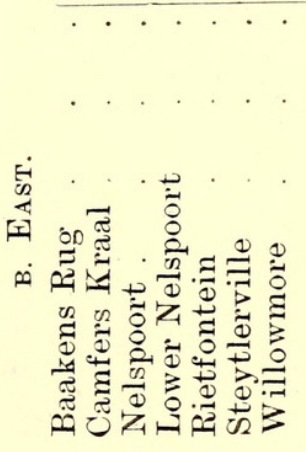 & \\
\hline
\end{tabular}




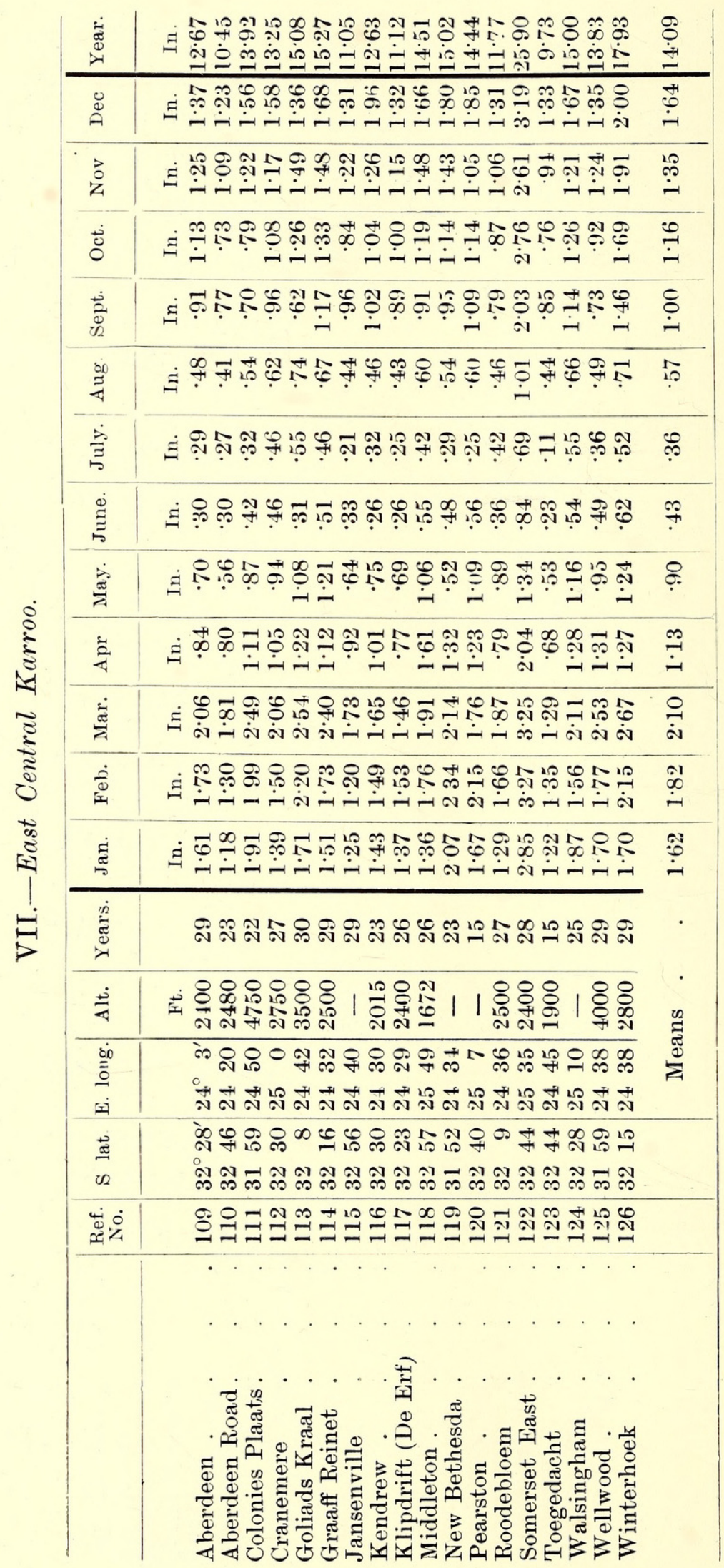


A Contribution to the Study of the Rainfall Map of South Africa.

\begin{tabular}{|c|c|}
\hline 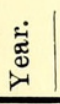 & 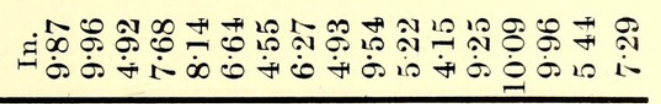 \\
\hline$\stackrel{\dot{\Xi}}{\cong}$ & 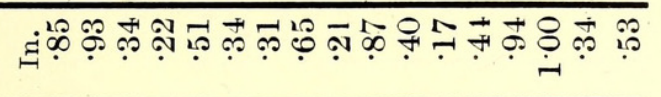 \\
\hline 客 & 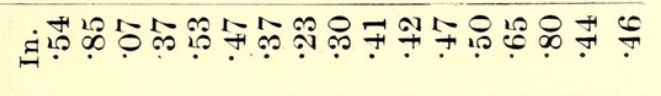 \\
\hline$\dot{8}$ & 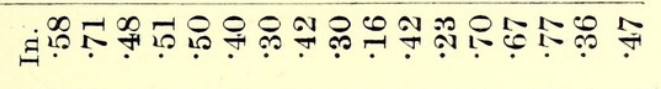 \\
\hline 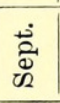 & 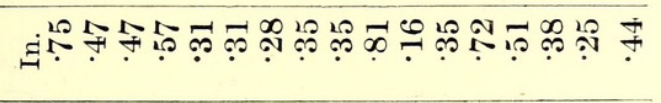 \\
\hline$\stackrel{800}{\sharp}$ & 白 \\
\hline$\stackrel{\Delta}{\Xi}$ & 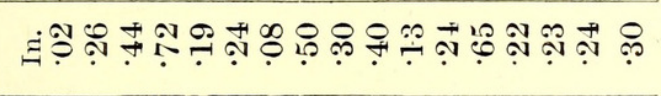 \\
\hline 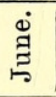 & 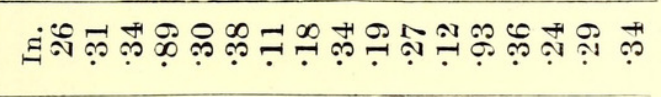 \\
\hline 灾 & 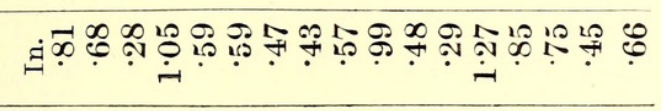 \\
\hline$\dot{\overrightarrow{4}}$ & 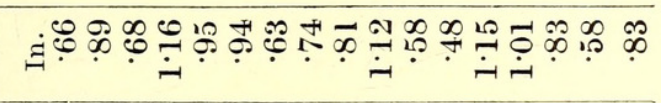 \\
\hline$\dot{\tilde{\Xi}}$ & 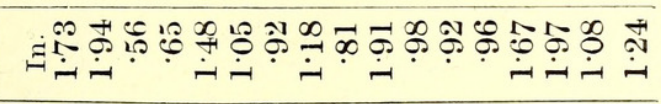 \\
\hline $\begin{array}{l}0 \\
0 \\
0\end{array}$ & 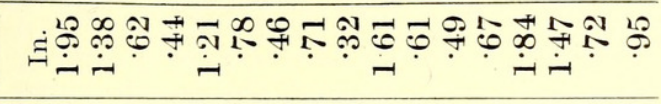 \\
\hline 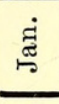 & 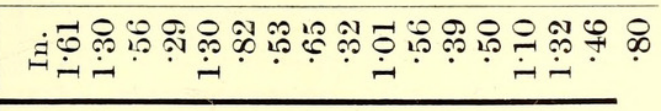 \\
\hline 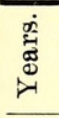 & 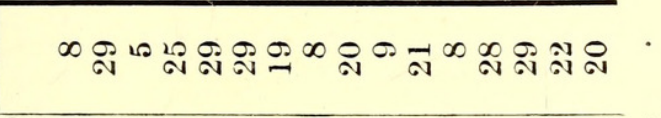 \\
\hline 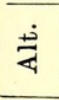 & 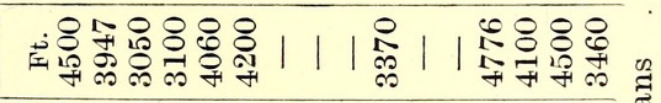 \\
\hline$\underset{\dot{0}}{\dot{0}}$ & 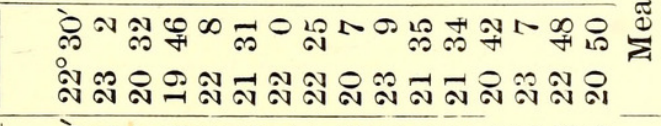 \\
\hline$\underset{\dot{\Phi}}{\dot{\Phi}}$ & 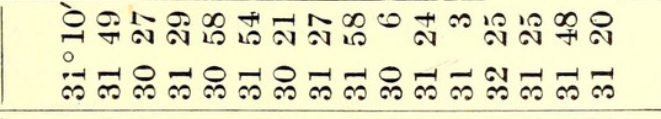 \\
\hline تُه & 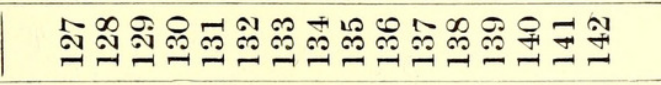 \\
\hline
\end{tabular}

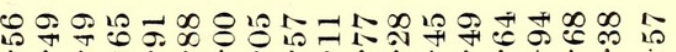

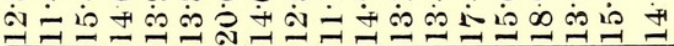

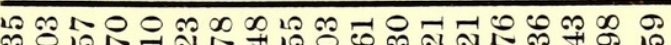

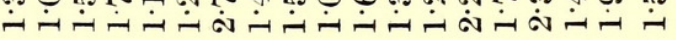

कำ "ำ

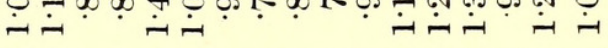

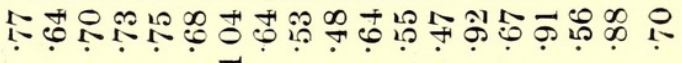

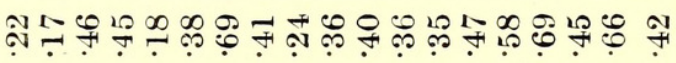

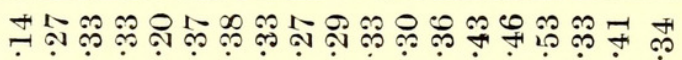

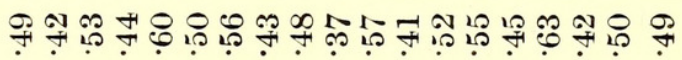

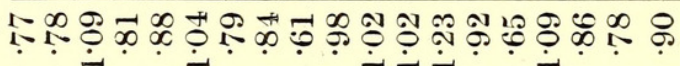

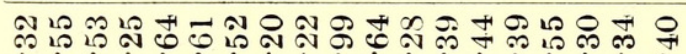
$\dot{\sim} \dot{-} \dot{-} \dot{-} \dot{-} \dot{-} \dot{-} \dot{-} \dot{-} \dot{-} \dot{-} \dot{-} \dot{-} \dot{-} \dot{-} \dot{-} \dot{-} \dot{-}$

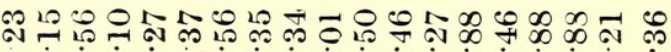
ง ำ

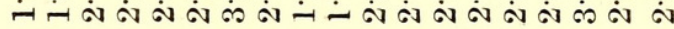

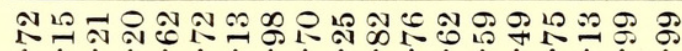

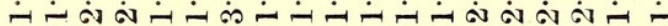

ำลลจ

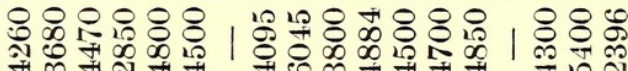

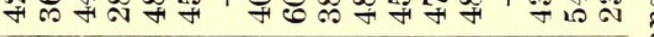

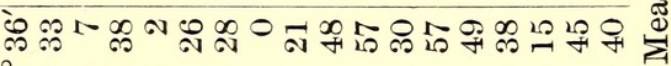

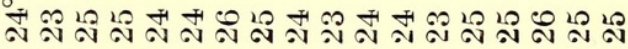

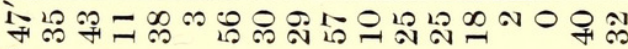

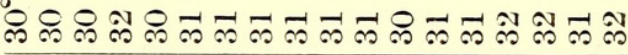

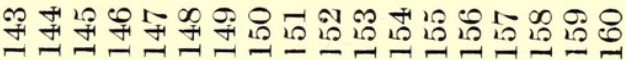
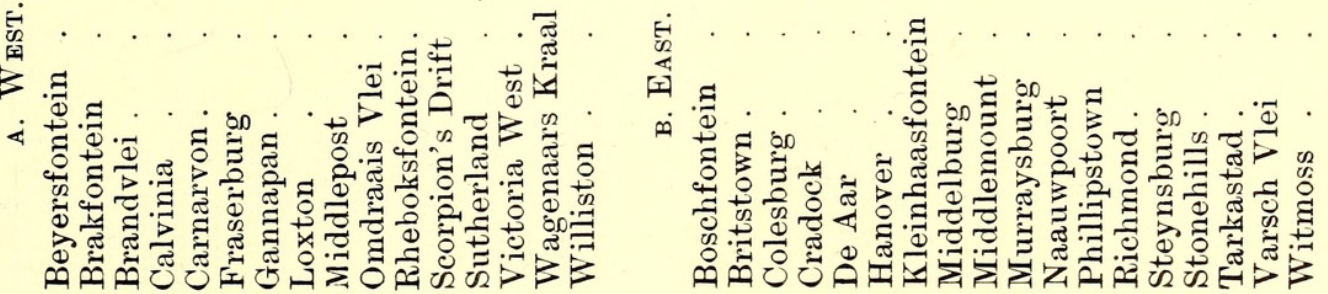


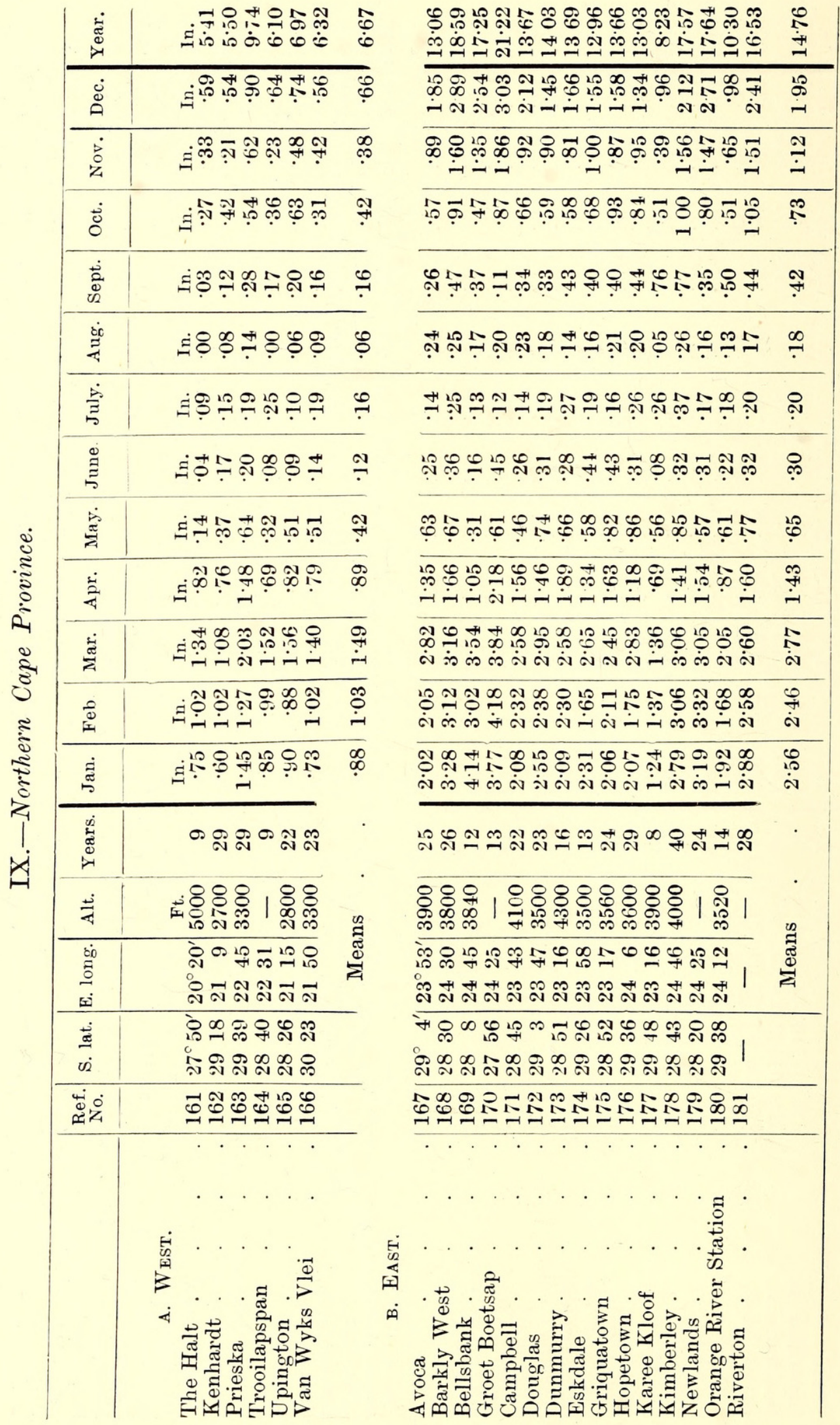


A Contribution to the Study of the Rainfall Map of South Africa. 397

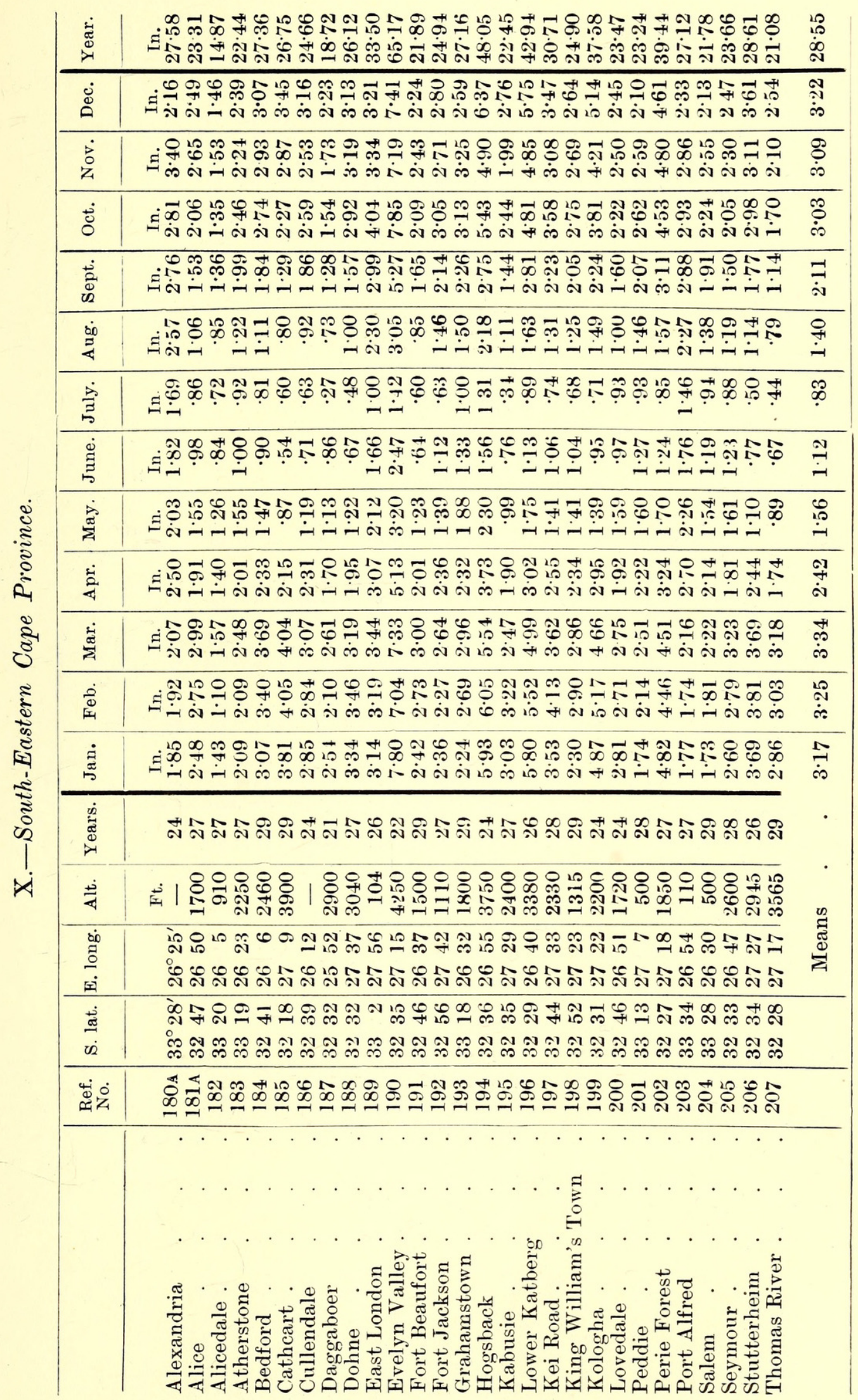


Transactions of the Royal Society of South Africa.

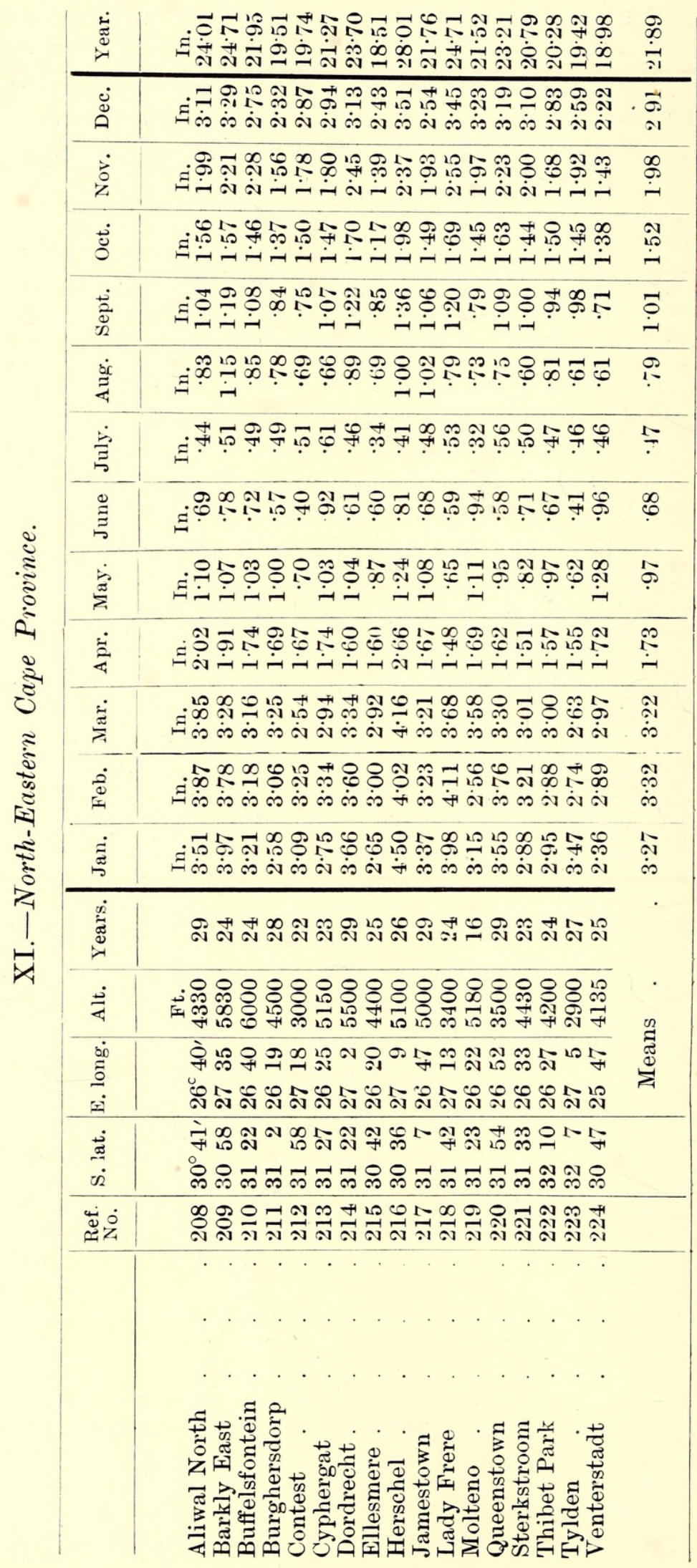


A Contribution to the Study of the Rainfall Map of South Africa. 399

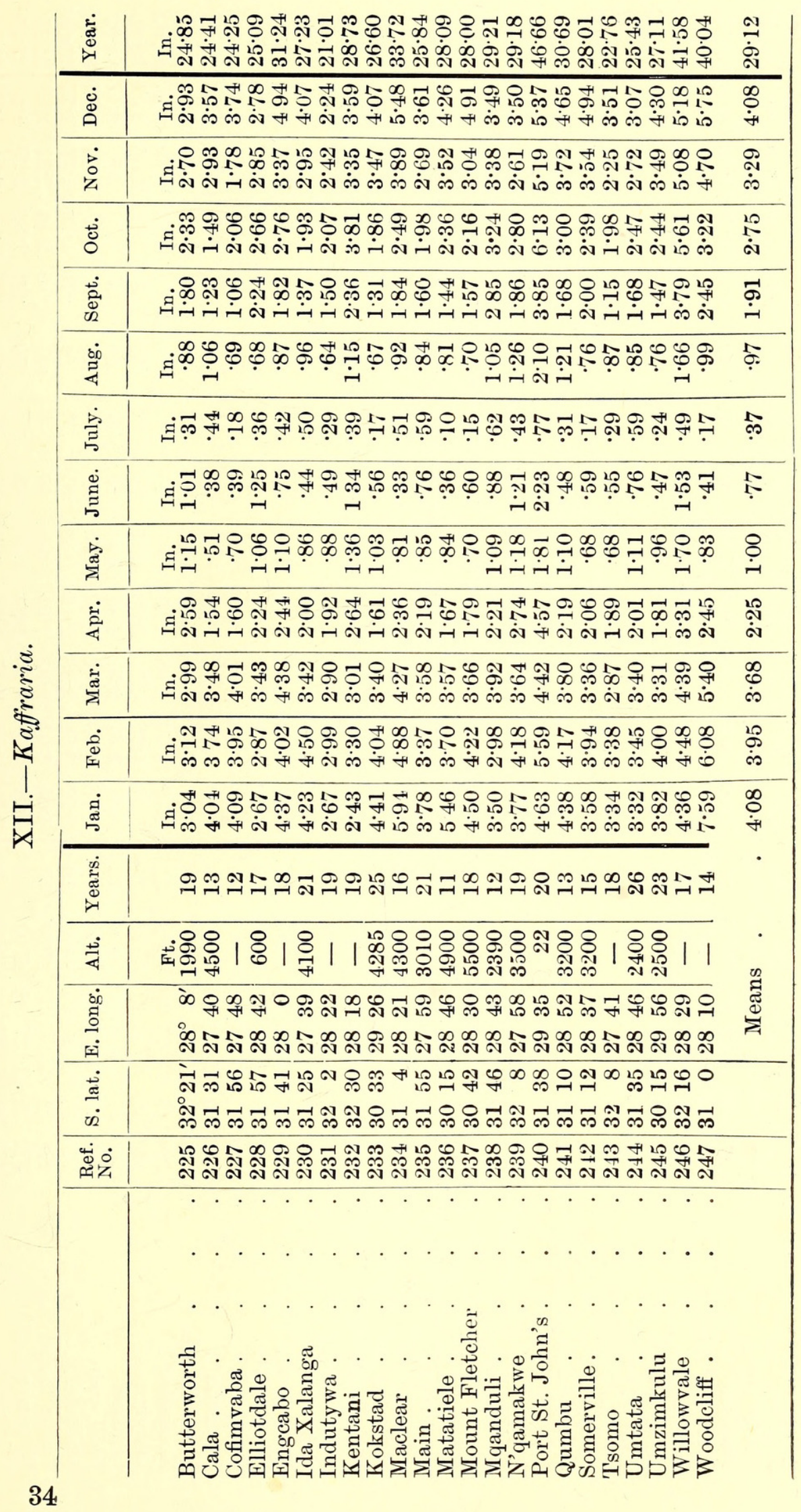




\begin{tabular}{|c|c|c|}
\hline & 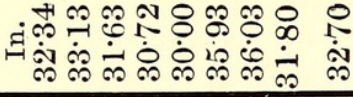 & 疍 \\
\hline & 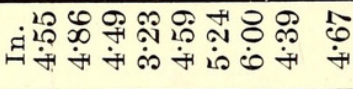 & 象 \\
\hline & 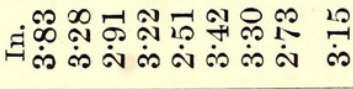 & के \\
\hline & 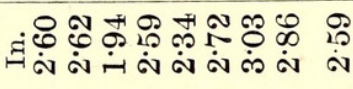 & i⿱ \\
\hline & 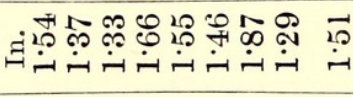 & $\overrightarrow{20}$ \\
\hline & 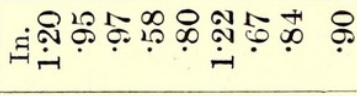 & \\
\hline & 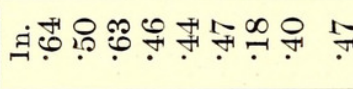 & \\
\hline & 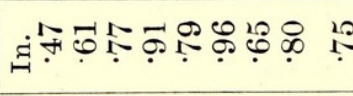 & \\
\hline & 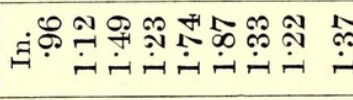 & 盏 \\
\hline & 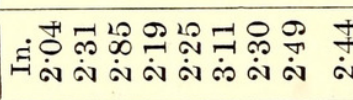 & 茫 \\
\hline & 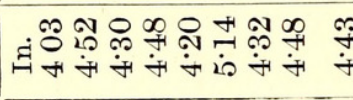 & 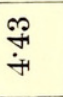 \\
\hline & 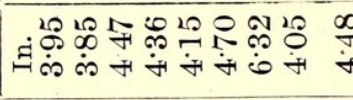 & $\underset{\infty}{\infty}$ \\
\hline & 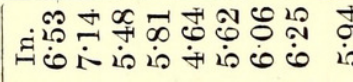 & Si \\
\hline & 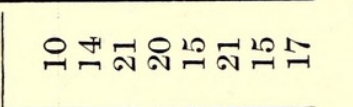 & \\
\hline & 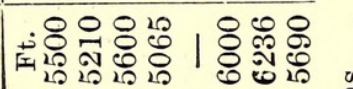 & \\
\hline & 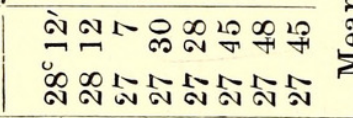 & 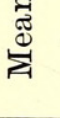 \\
\hline & 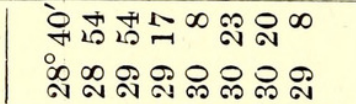 & \\
\hline & 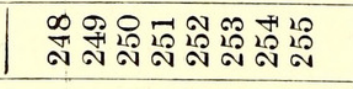 & \\
\hline & 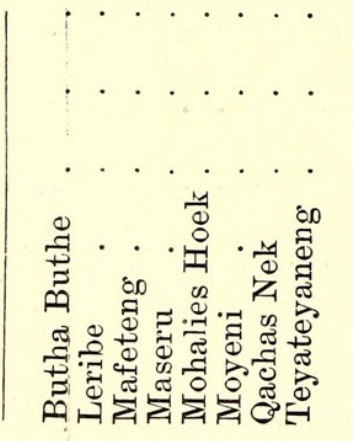 & \\
\hline
\end{tabular}

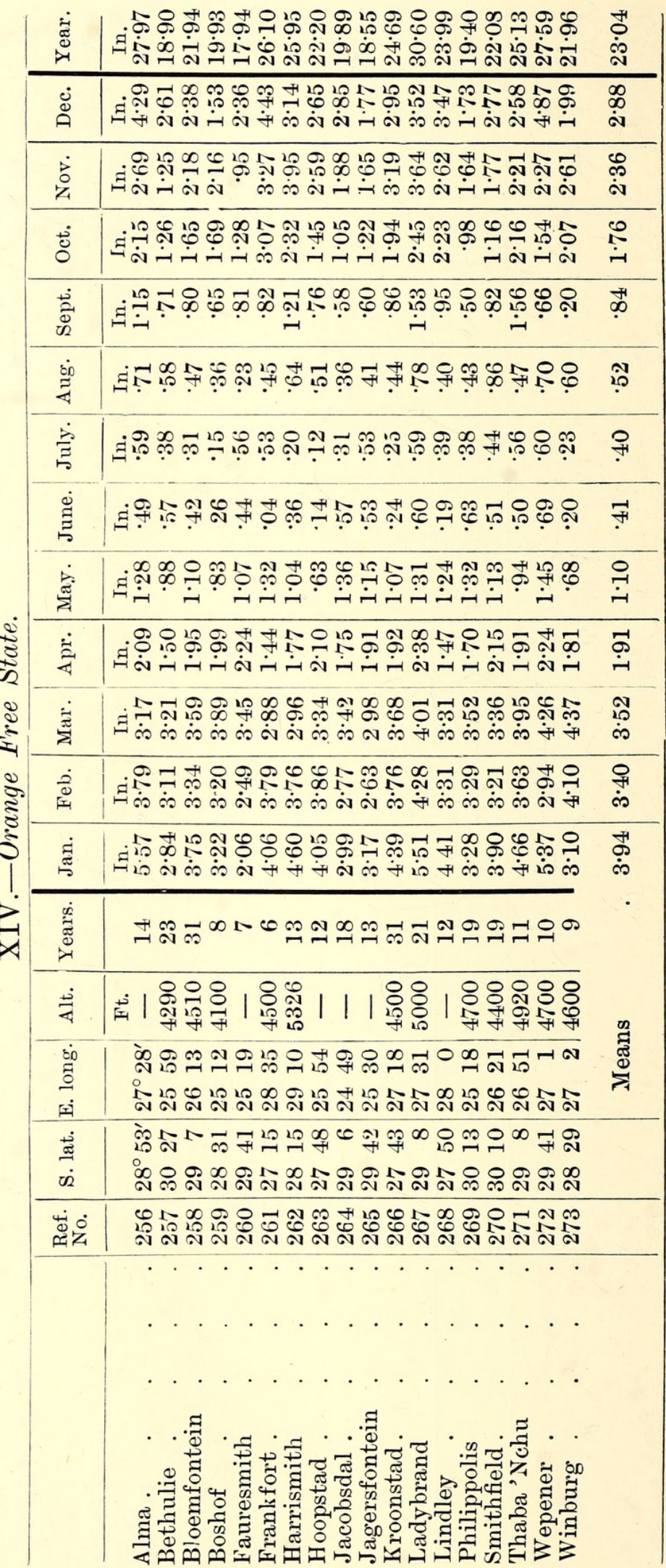


A Contribution to the Study of the Rainfall Map of South Africa. 401

\begin{tabular}{|c|c|c|}
\hline$\dot{\vec{\Xi}}$ & 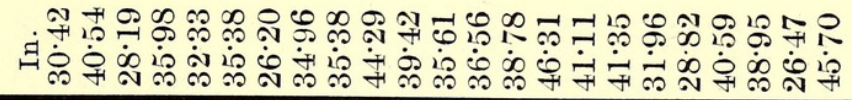 & 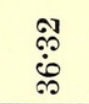 \\
\hline$\dot{\Xi}$ & 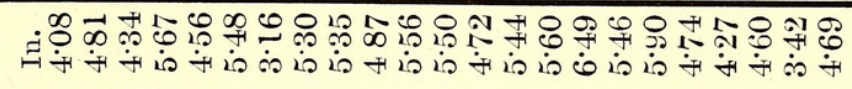 & $\begin{array}{c}\mathscr{\varphi} \\
\stackrel{+}{+}\end{array}$ \\
\hline 客 & 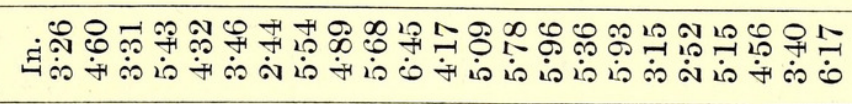 & 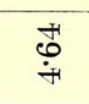 \\
\hline$\dot{0}$ & 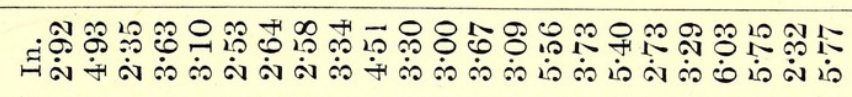 & $\underset{10}{10}$ \\
\hline 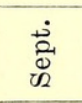 & 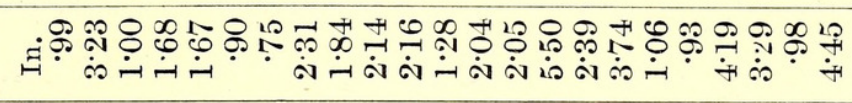 & $\stackrel{\substack{M \\
\text { ì }}}{ }$ \\
\hline$\dot{\dot{x}} \overrightarrow{\dot{u}}$ & 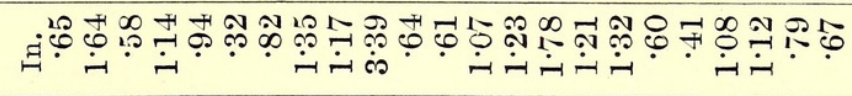 & $\stackrel{1}{\grave{9}}$ \\
\hline$\stackrel{B}{\rightrightarrows}$ & 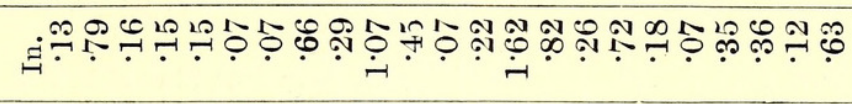 & F \\
\hline 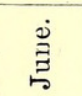 & 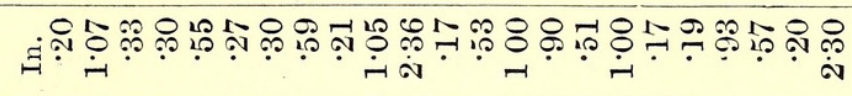 & $\stackrel{\infty}{0}$ \\
\hline 宏 & 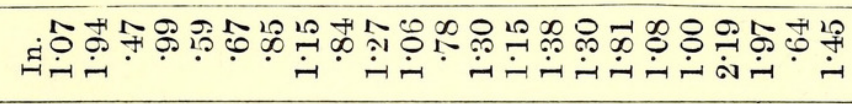 & $\stackrel{1}{\rightleftharpoons}$ \\
\hline 安 & 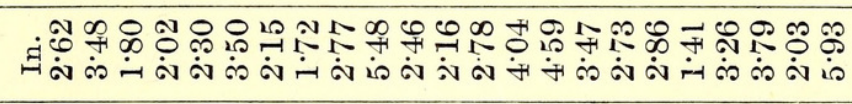 & $\begin{array}{l}\mathscr{O}_{0} \\
\dot{\varphi}\end{array}$ \\
\hline 芫 & 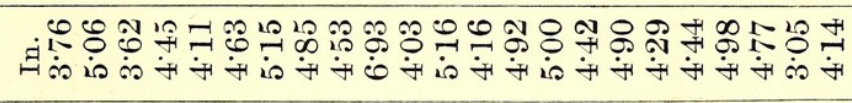 & 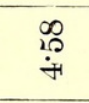 \\
\hline$\dot{\overrightarrow{0}}$ & 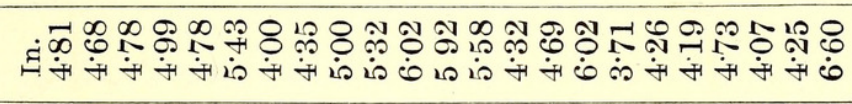 & $\underset{\substack{\infty \\
\dot{+}+}}{\infty}$ \\
\hline 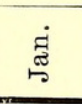 & 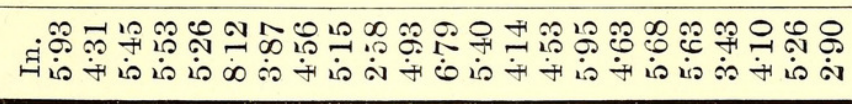 & $\stackrel{\mathscr{L}}{\mathscr{+}}$ \\
\hline 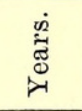 & 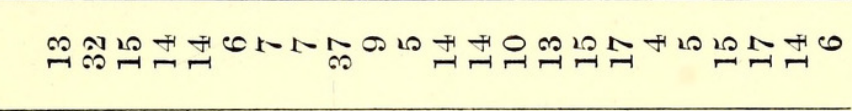 & \\
\hline 这 & 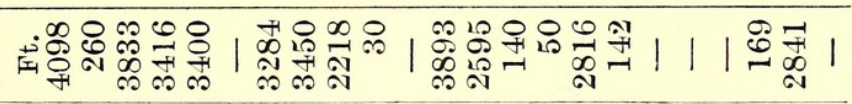 & $\cdot$ \\
\hline $\begin{array}{l}\dot{0} 0 \\
\stackrel{0}{0} \\
\dot{9}\end{array}$ & 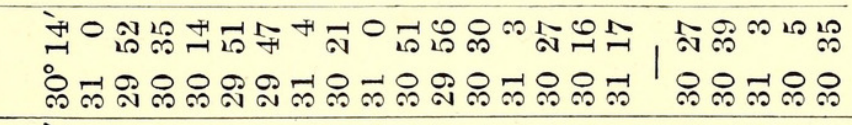 & 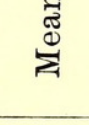 \\
\hline$\underset{\dot{a}}{\dot{\omega}}$ & 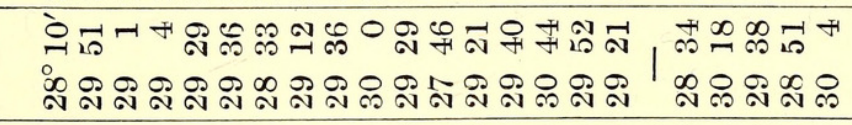 & \\
\hline 崩完 & 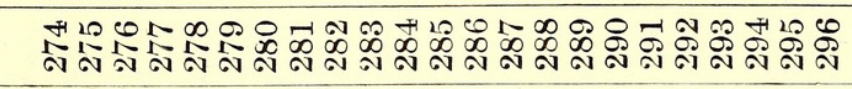 & \\
\hline & $\begin{array}{c}\cdots \\
\cdots \\
\cdots\end{array} \ldots \ldots \ldots$ & \\
\hline
\end{tabular}




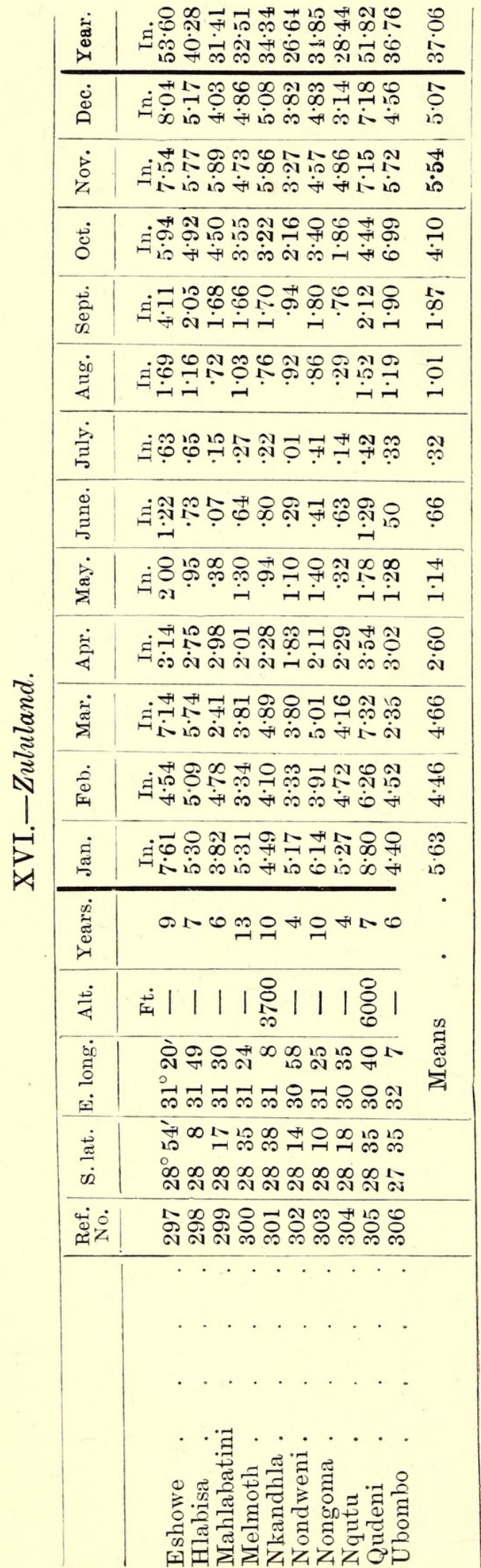

\begin{tabular}{|c|c|c|}
\hline 芯 & 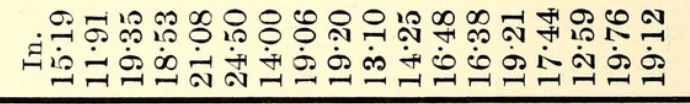 & 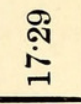 \\
\hline ळ̊ं & 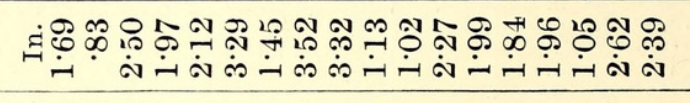 & $\stackrel{20}{i}$ \\
\hline 言 & 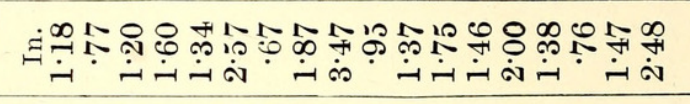 & $\stackrel{10}{\leftrightarrow}$ \\
\hline$\dot{\overrightarrow{0}}$ & 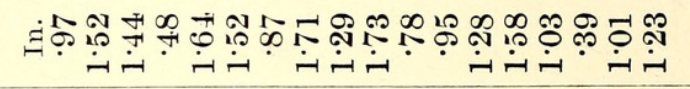 & $\stackrel{9}{-}$ \\
\hline $\begin{array}{l}\text { 产 } \\
\text { on } \\
\text { On }\end{array}$ & ఏํำ & F \\
\hline$\dot{80}$ & 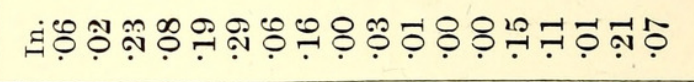 & ? \\
\hline$\stackrel{\dot{b}}{\rightrightarrows}$ & 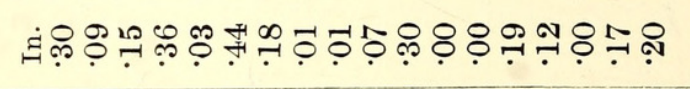 & $\stackrel{20}{-7}$ \\
\hline 离 & ઘં & $\stackrel{\infty}{\rightarrow}$ \\
\hline 窝 & 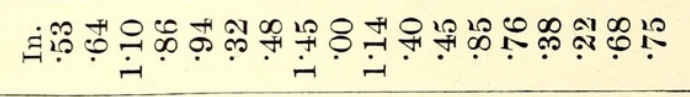 & 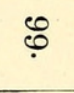 \\
\hline$\dot{\vec{a}}$ & 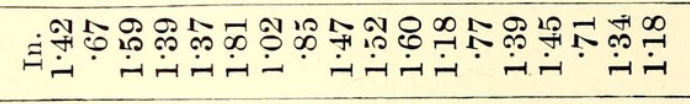 & $\stackrel{\mathscr{\oplus}}{\stackrel{\oplus}{-1}}$ \\
\hline 芯 & 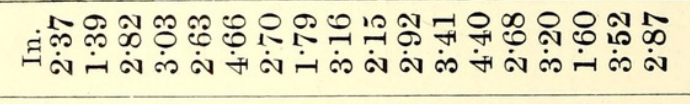 & $\begin{array}{l}10 \\
\dot{m} \\
\dot{\infty}\end{array}$ \\
\hline$\dot{\overrightarrow{0}}$ & 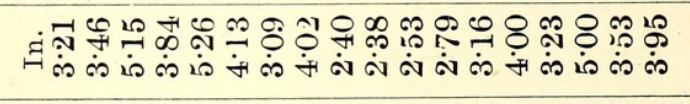 & 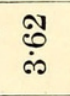 \\
\hline$\stackrel{\tilde{\Xi}}{\check{g}}$ & 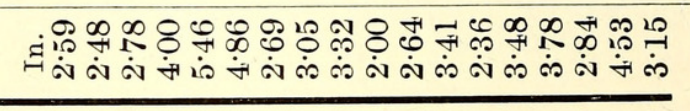 & $\begin{array}{l}\stackrel{\rho}{\infty} \\
\dot{m}\end{array}$ \\
\hline 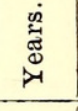 & $0,0 \mathrm{~N}$ & \\
\hline$\stackrel{+3}{4}$ & 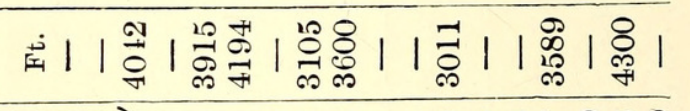 & ? \\
\hline $\begin{array}{l}\dot{\infty} 0 \\
\stackrel{\Xi}{\dot{0}} \\
\dot{1}\end{array}$ & 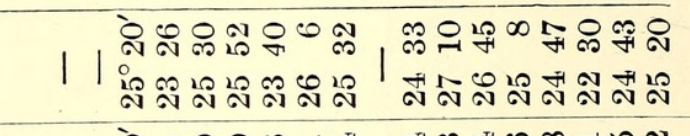 & 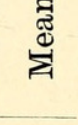 \\
\hline$\underset{\dot{\Xi}}{\dot{\Xi}}$ & 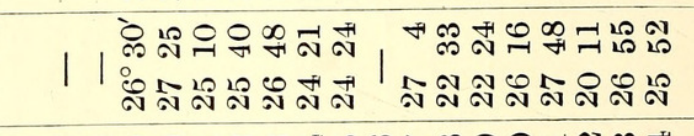 & \\
\hline 悹宗 & 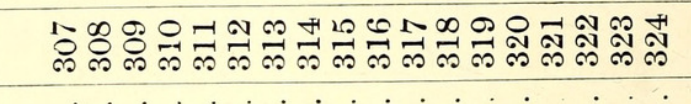 & \\
\hline & $\begin{array}{c}\cdots \\
\ldots\end{array}$ & \\
\hline
\end{tabular}




\begin{tabular}{|c|c|c|}
\hline 莡 & 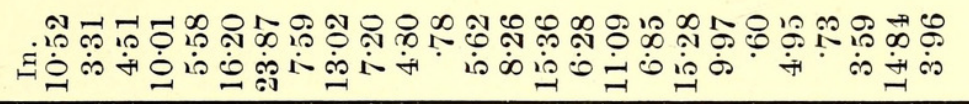 & 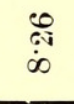 \\
\hline 悹 & 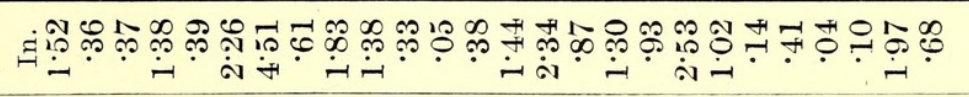 & $\stackrel{\sim}{\stackrel{\sim}{-}}$ \\
\hline 客 & 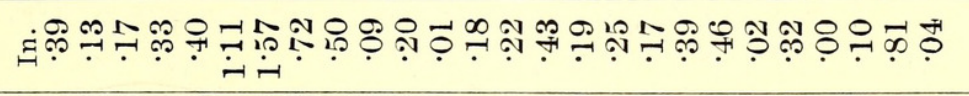 & קִ \\
\hline$\dot{\ddot{\Xi}}$ & 过ำㅇำ & 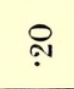 \\
\hline 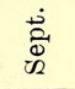 & 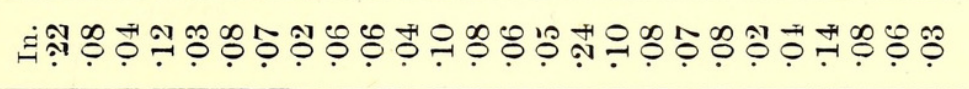 & $\stackrel{\infty}{\rho}$ \\
\hline 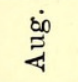 & 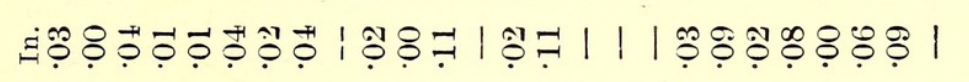 & $\dddot{\varphi}$ \\
\hline 官 & घं | & ڤొ \\
\hline$\stackrel{\Xi}{\Xi}$ & 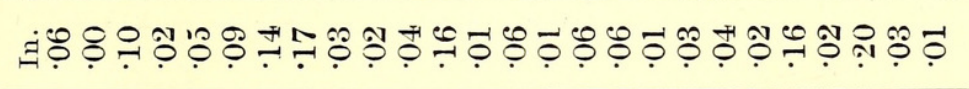 & $\ddot{\varphi}$ \\
\hline 窟 & 范 & $\ddot{z}$ \\
\hline$\dot{\overrightarrow{\ddot{4}}}$ & 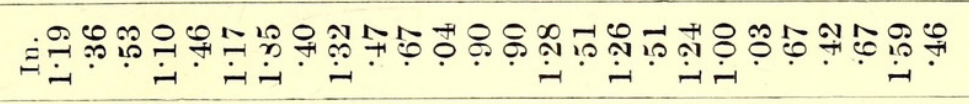 & $\vec{\infty}$ \\
\hline 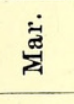 & 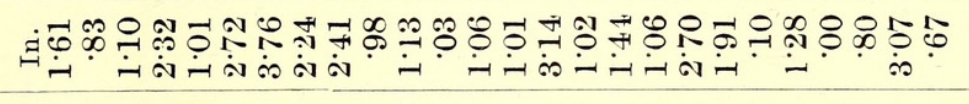 & $\stackrel{\cap}{\stackrel{D}{g}}$ \\
\hline$\underset{\substack{0 \\
\sum_{1}}}{\dot{0}}$ & 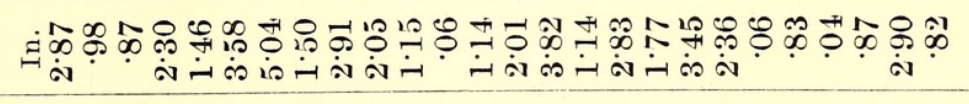 & $\stackrel{\infty}{\infty}$ \\
\hline జّं & 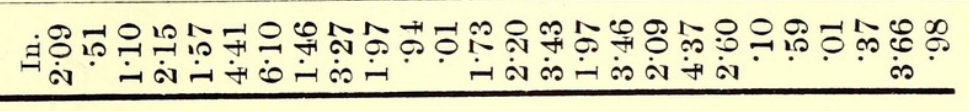 & $\overrightarrow{\grave{i}}$ \\
\hline 峁 & 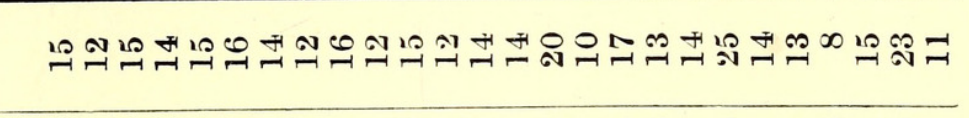 & \\
\hline$\dot{\vec{z}}$ & 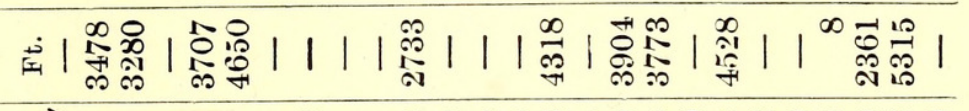 & $\stackrel{n}{\Rightarrow}$ \\
\hline $\begin{array}{l}\dot{0} 0 \\
\dot{=} \\
\dot{m}\end{array}$ & 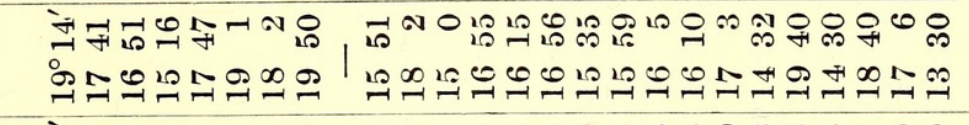 & 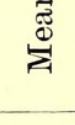 \\
\hline 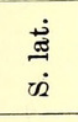 & 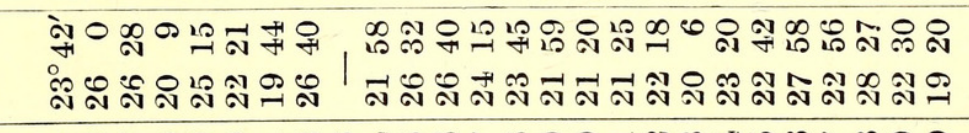 & \\
\hline & 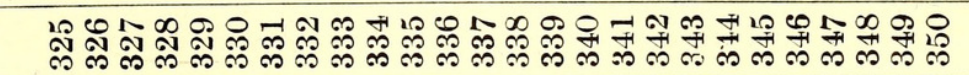 & \\
\hline
\end{tabular}

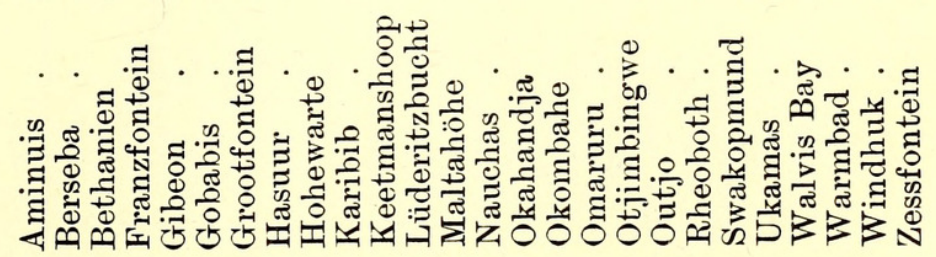




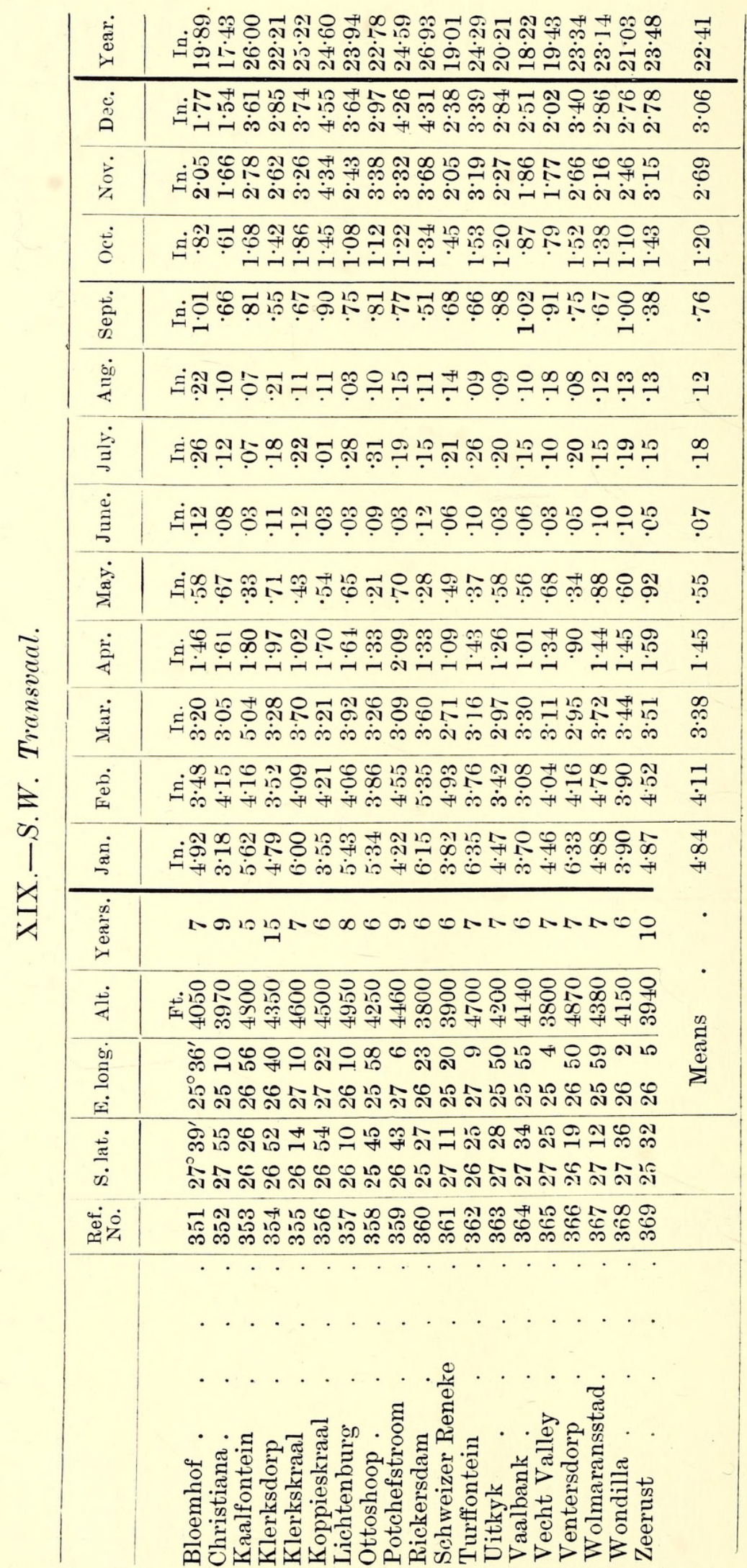


A Contribution to the Study of the Rainfall Map of South Africa. 405

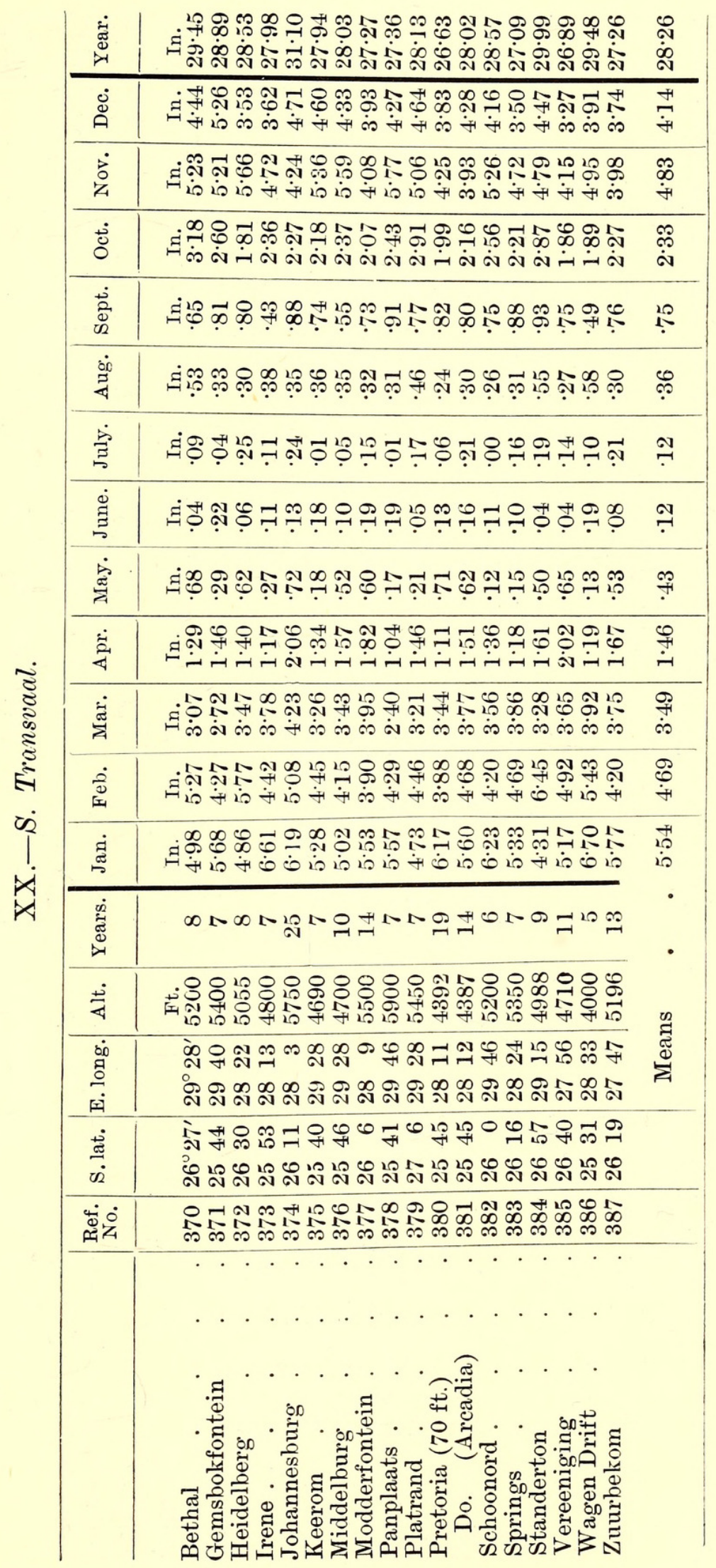




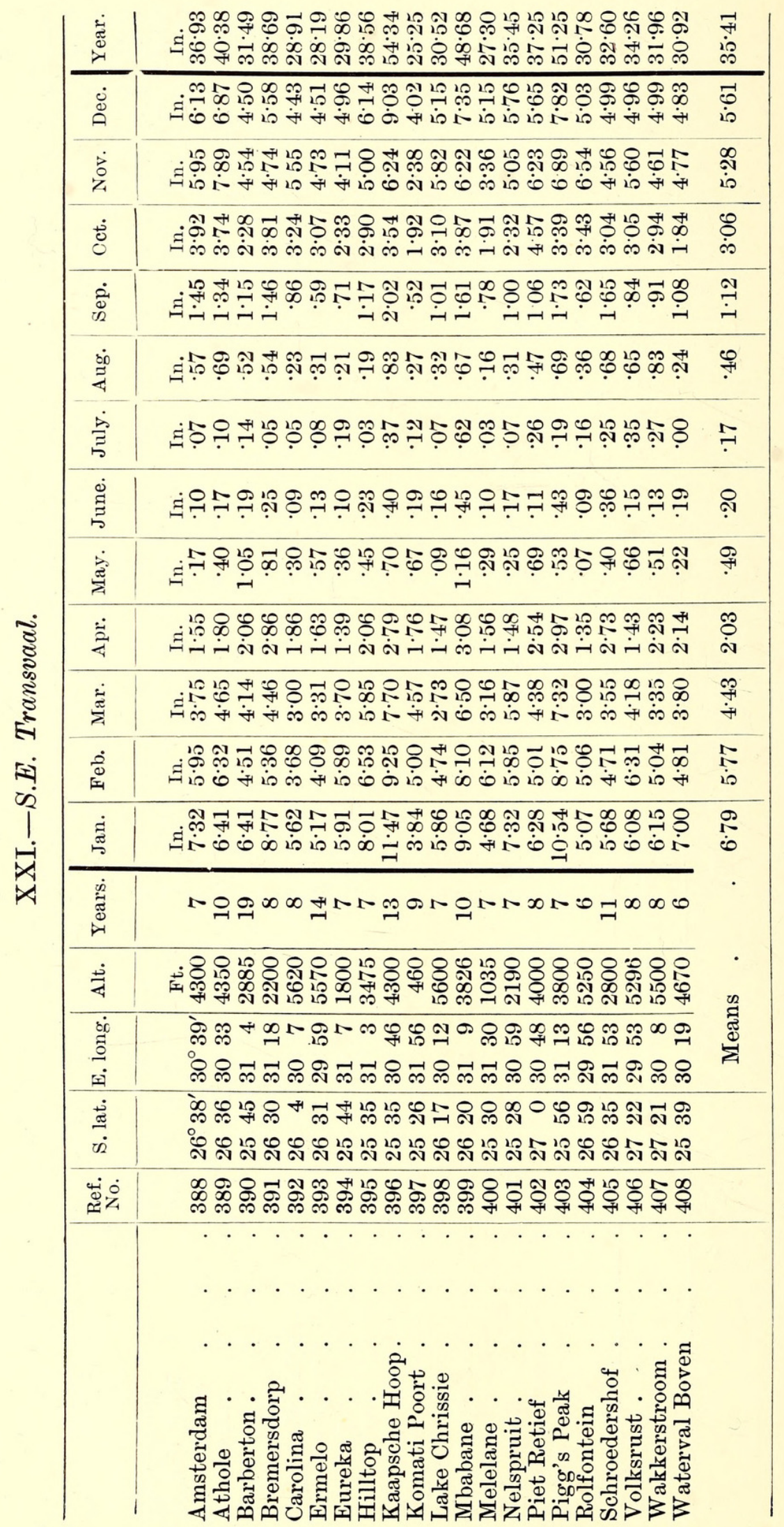


A Contribution to the Study of the Rainfall Map of South Africa. 407

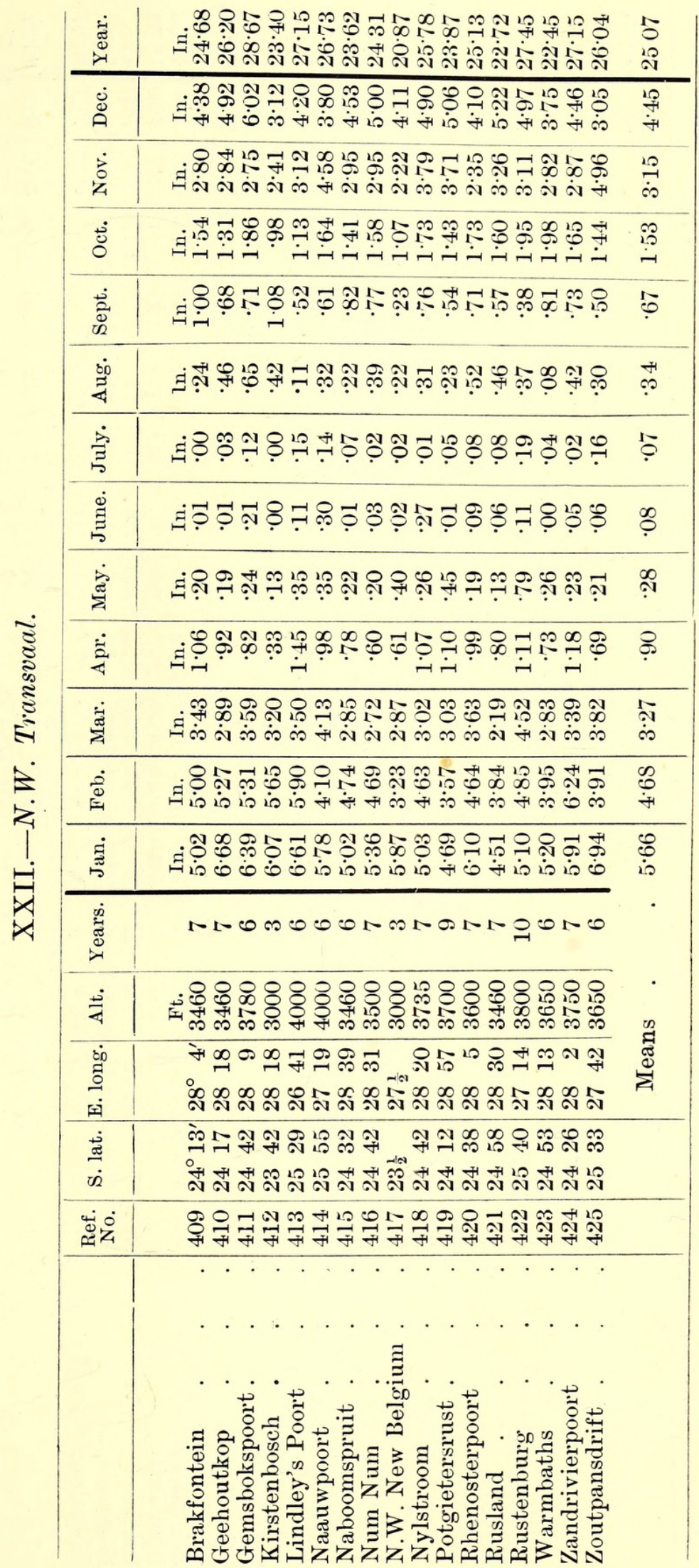




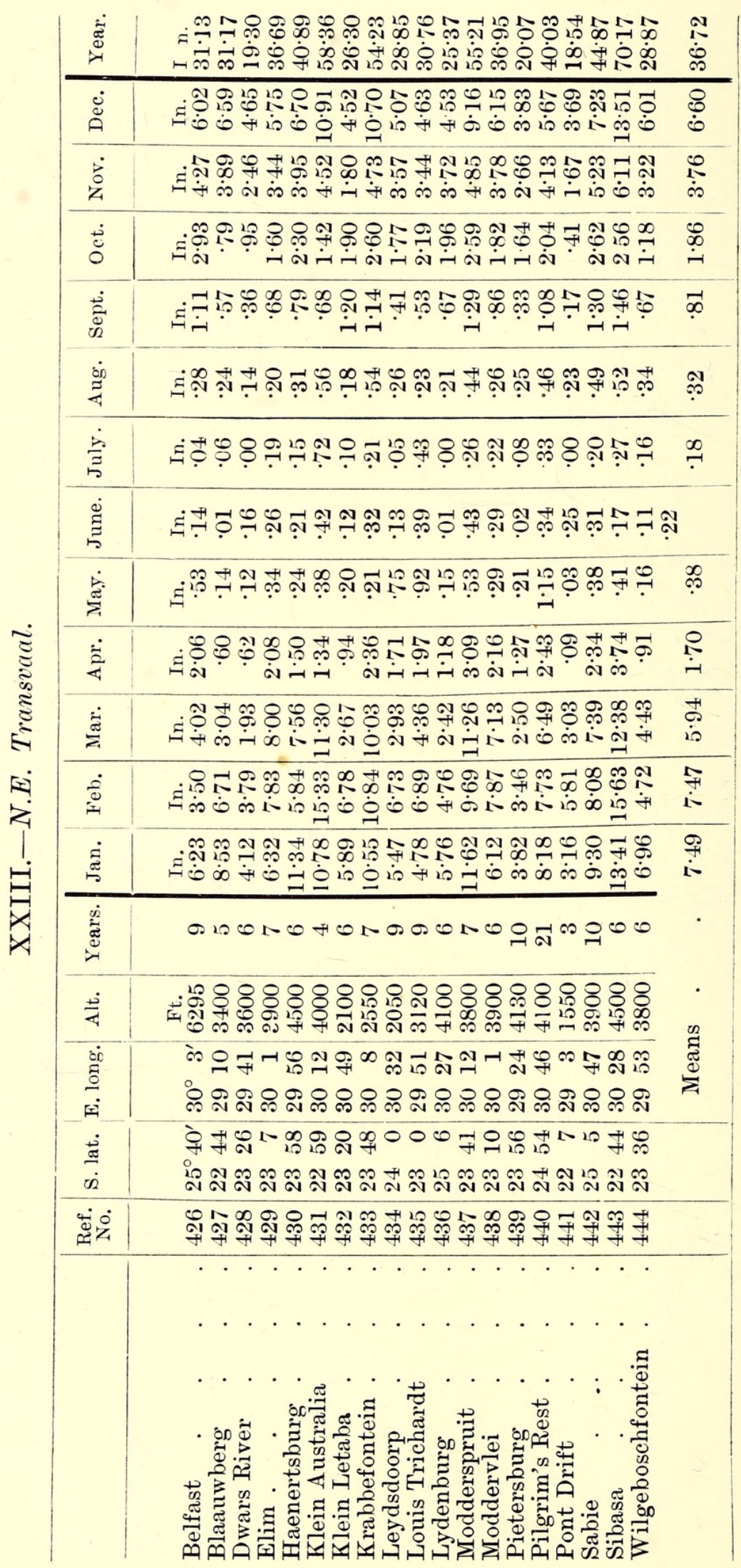


A Contribution to the Study of the Rainfall Map of South Africa. 409

\begin{tabular}{|c|c|c|}
\hline 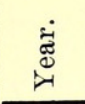 & 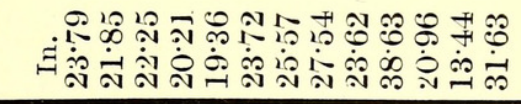 & $\begin{array}{l}\ddot{0} \\
\dot{+} \\
\text { Sit }\end{array}$ \\
\hline$\dot{\Phi}$ & 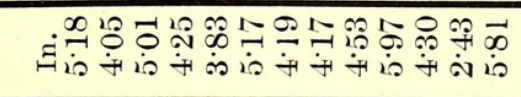 & 管 \\
\hline$\dot{0}$ & 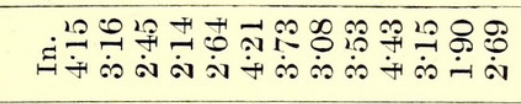 & $\overrightarrow{\dot{\varphi}}$ \\
\hline$\dot{\dot{0}}$ & نَّ & $\stackrel{\stackrel{\leftrightarrow}{\oplus}}{-}$ \\
\hline 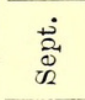 & 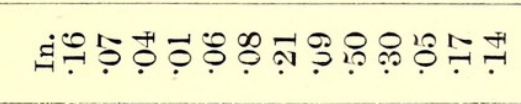 & 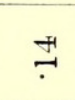 \\
\hline$\frac{\dot{90}}{\nexists}$ & घં & $\dddot{\varphi}$ \\
\hline$\stackrel{\dot{b}}{\vec{g}}$ & 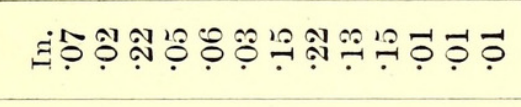 & †े \\
\hline$\stackrel{\Xi}{\Xi}$ & ذ̇ & $\%$ \\
\hline 宏 & 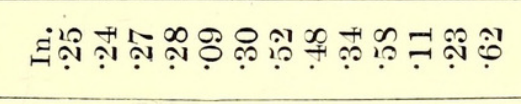 & $\dddot{q}$ \\
\hline$\dot{\ddot{\Xi}}$ & 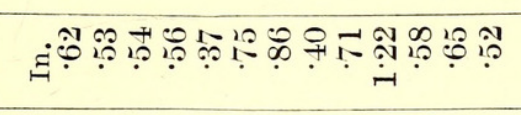 & "艹 \\
\hline$\dot{\tilde{\Xi}}$ & 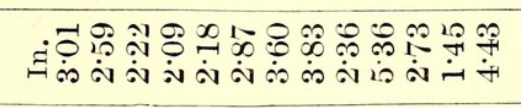 & $\underset{\dot{\omega}}{\infty}$ \\
\hline$\underset{\dot{0}}{\dot{0}}$ & 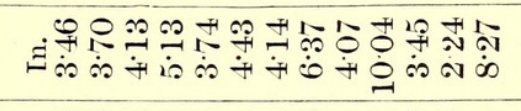 & $\underset{\infty}{\infty}$ \\
\hline$\dot{\tilde{\tilde{E}}}$ & 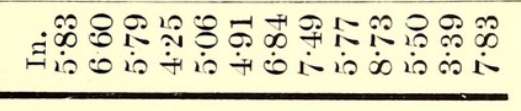 & $\stackrel{8}{0}$ \\
\hline 离 & 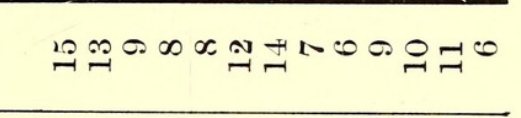 & $\cdot$ \\
\hline$\dot{\overrightarrow{4}}$ & 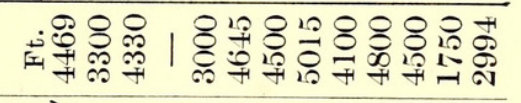 & $\cdot$ \\
\hline 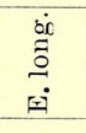 & 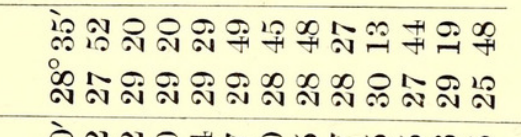 & 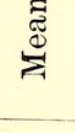 \\
\hline 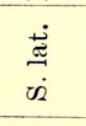 & 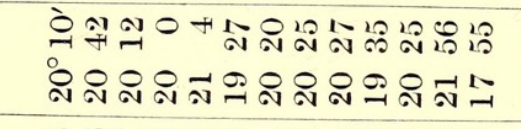 & \\
\hline 这 & 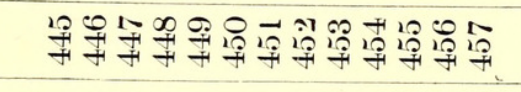 & \\
\hline & 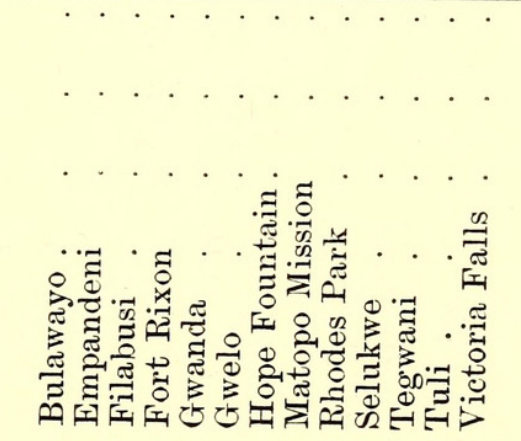 & \\
\hline
\end{tabular}




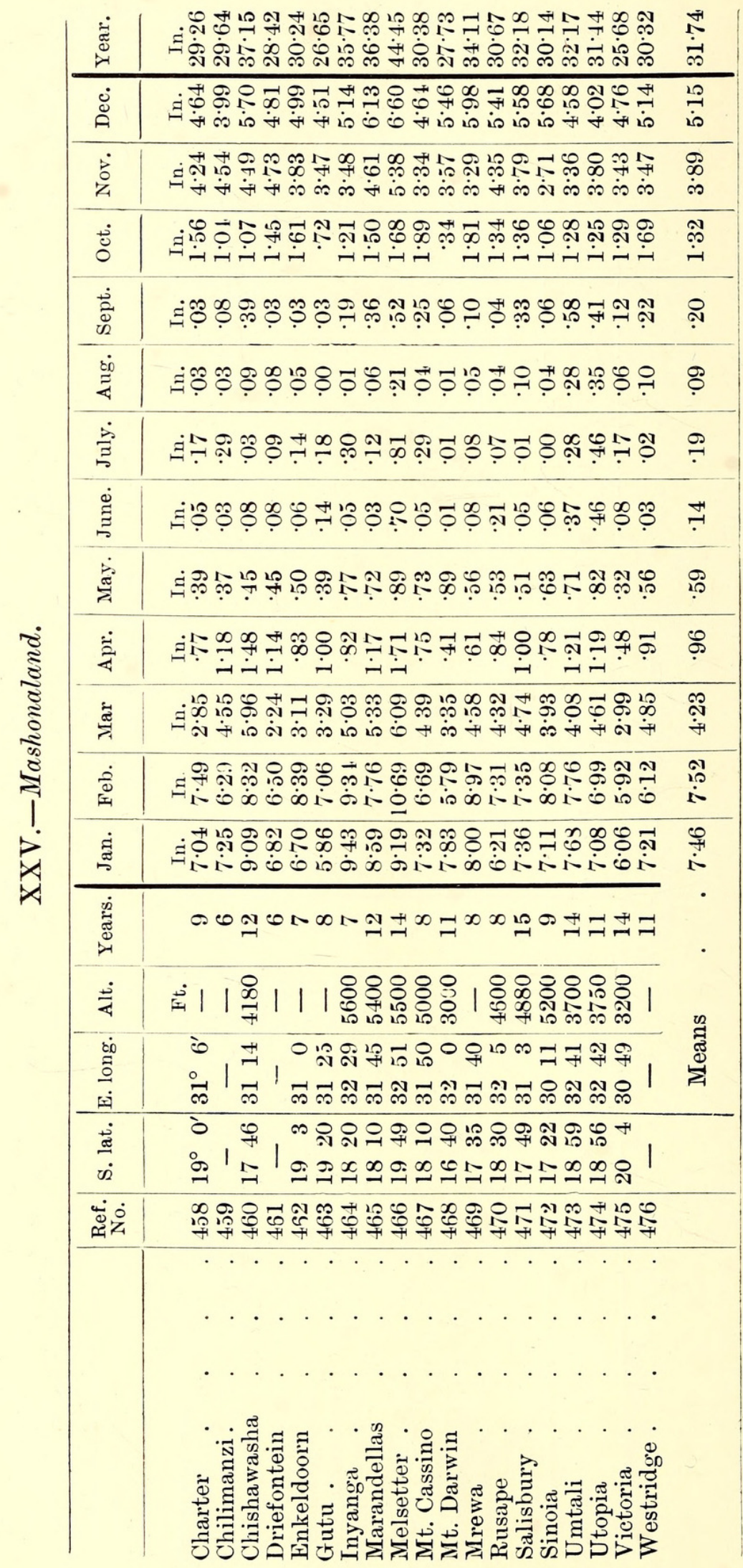


A Contribution to the Stidy of the Rainfall Map of South Africa. 411

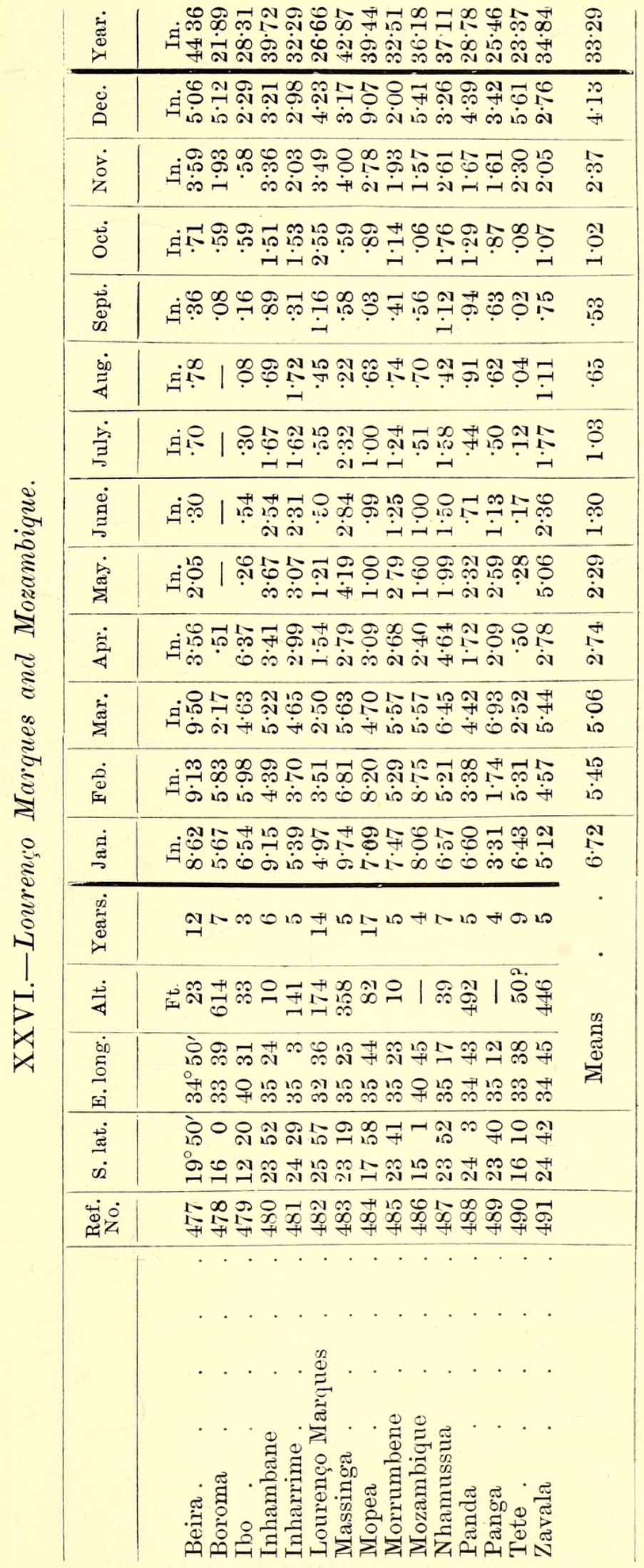




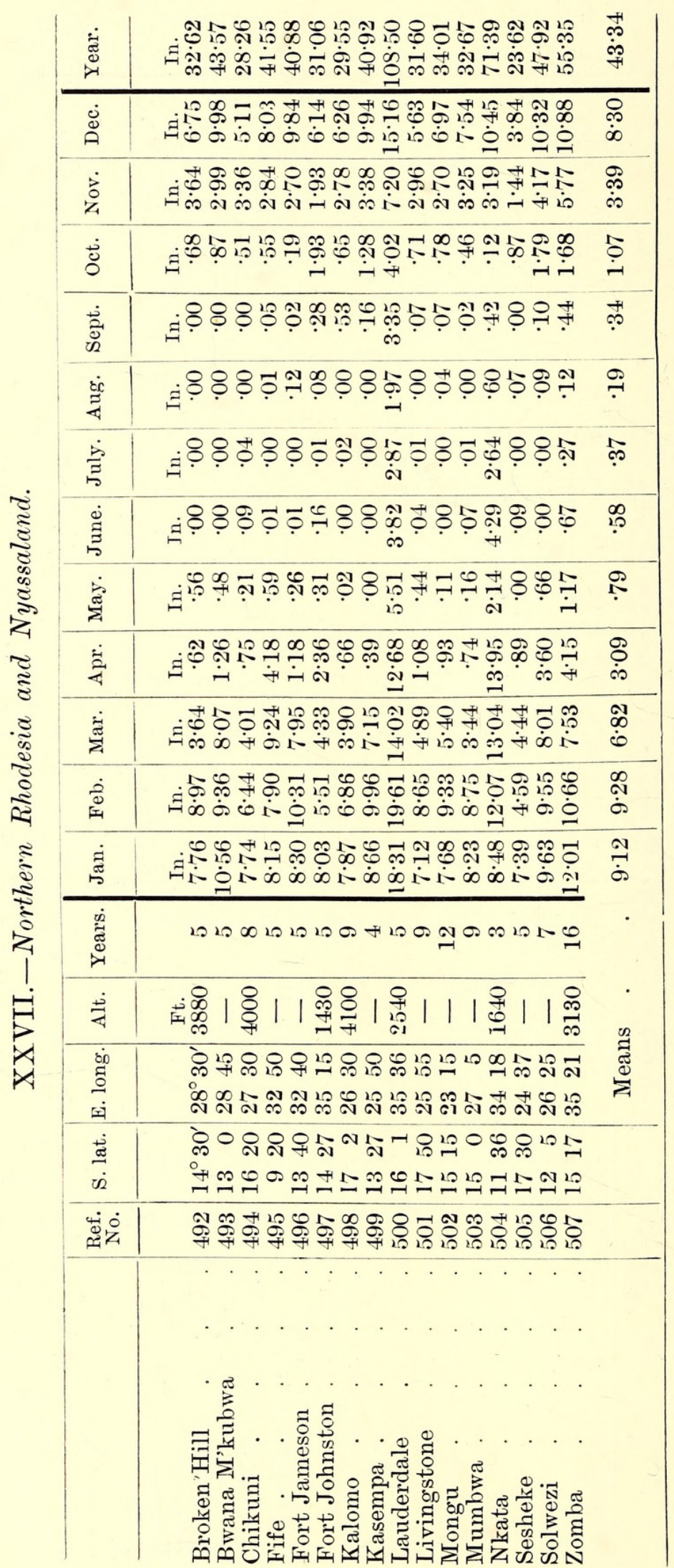




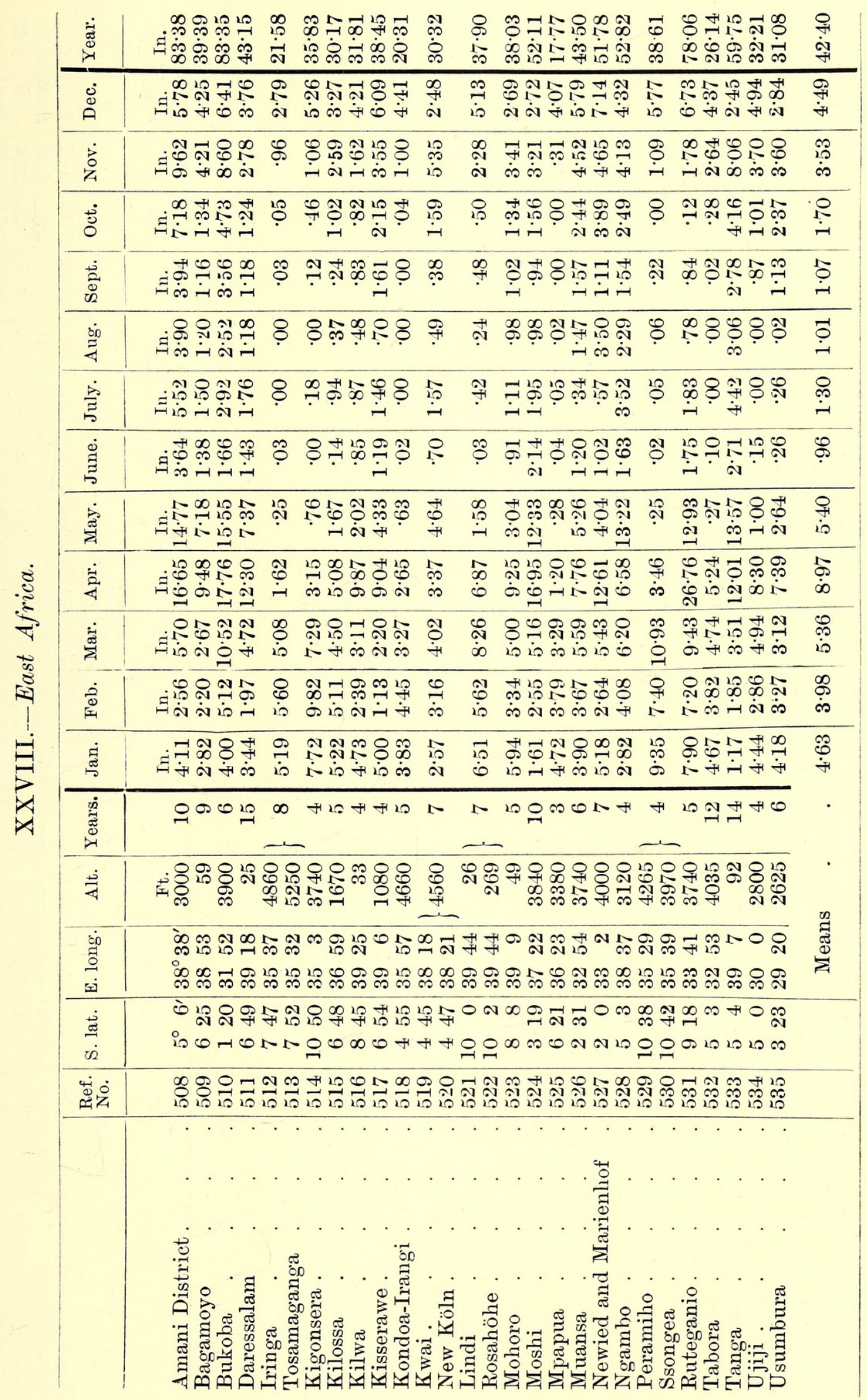




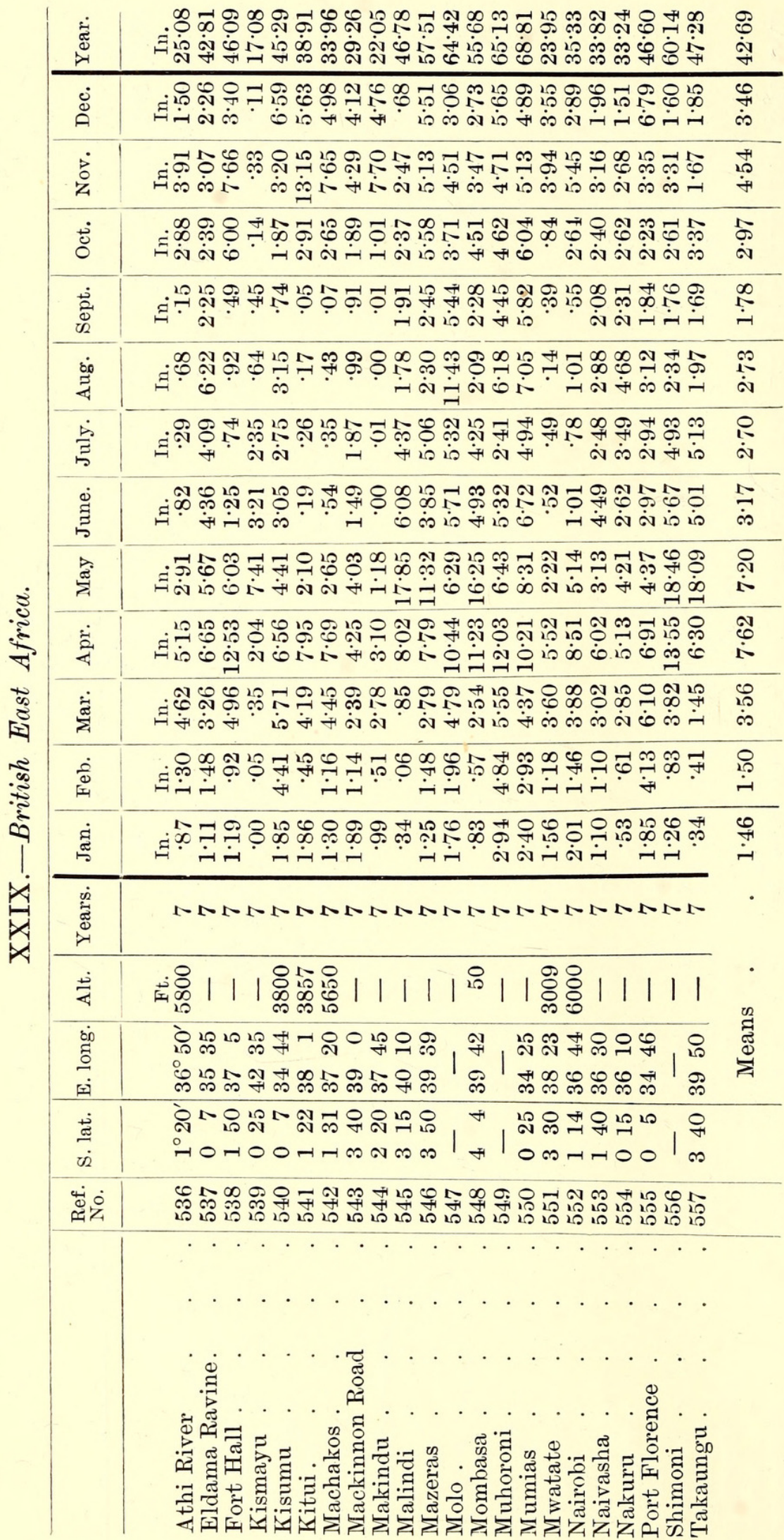

\begin{tabular}{|c|c|}
\hline$\underset{\check{\Xi}}{\infty}$ & 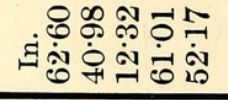 \\
\hline$\dot{\mathscr{\Xi}}$ & 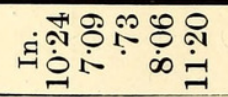 \\
\hline 宫 & 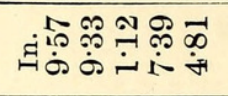 \\
\hline$\dot{0}$ & 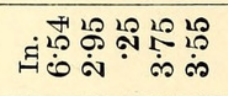 \\
\hline 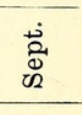 & 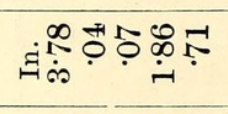 \\
\hline$\stackrel{\dot{0}}{4}$ & 岁 \\
\hline$\stackrel{\dot{b}}{\vec{b}}$ & 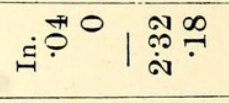 \\
\hline 节 & 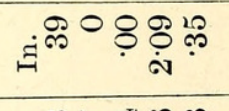 \\
\hline 密 & 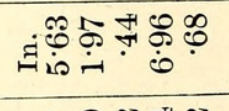 \\
\hline$\dot{\ddot{4}}$ & 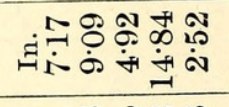 \\
\hline 运 & 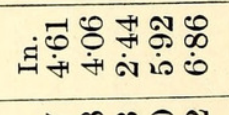 \\
\hline $\begin{array}{l}\dot{0} \\
\text { क्ष } \\
\end{array}$ & 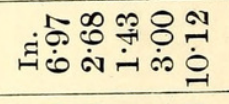 \\
\hline 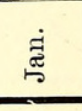 & 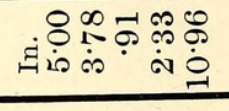 \\
\hline 离 & $10 \ln ^{20} 201$ \\
\hline$\dot{\vec{u}}$ & 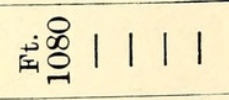 \\
\hline $\begin{array}{l}\dot{00} \\
\dot{0} \\
\dot{a}\end{array}$ & 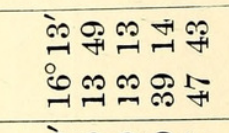 \\
\hline 茝 & 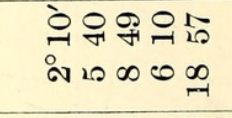 \\
\hline 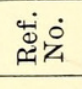 & 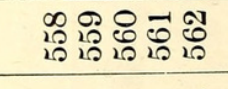 \\
\hline & 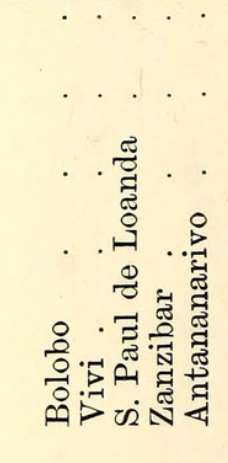 \\
\hline
\end{tabular}




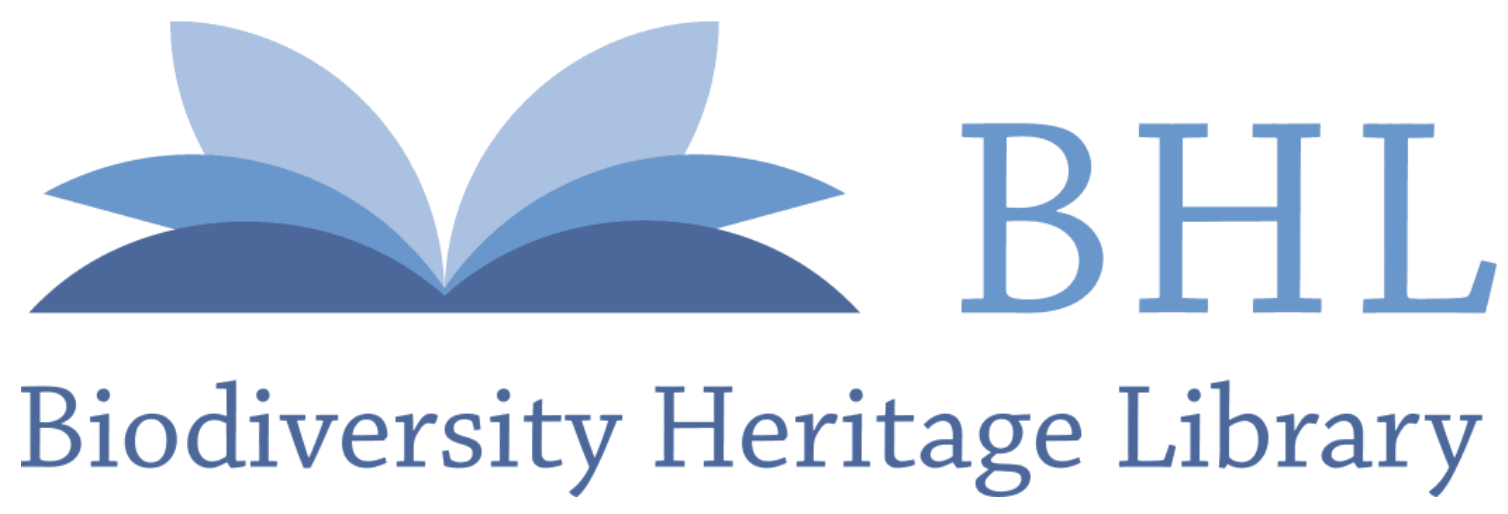

Sutton, J R . 1921. "A CONTRIBUTION TO THE STUDY OF THE RAINFALL MAP

OF SOUTH AFRICA." Transactions of the Royal Society of South Africa 9, 367-414. https://doi.org/10.1080/00359192109520224.

View This Item Online: https://www.biodiversitylibrary.org/item/181591

DOI: https://doi.org/10.1080/00359192109520224

Permalink: https://www.biodiversitylibrary.org/partpdf/175620

\section{Holding Institution}

Smithsonian Libraries

\section{Sponsored by}

Biodiversity Heritage Library

\section{Copyright \& Reuse}

Copyright Status: Not in copyright. The BHL knows of no copyright restrictions on this item.

This document was created from content at the Biodiversity Heritage Library, the world's largest open access digital library for biodiversity literature and archives. Visit BHL at https://www.biodiversitylibrary.org. 